\title{
Detection of Hypoxia in Cancer Models: Significance, Challenges, and Advances
}

\author{
Inês Godet ${ }^{1,2,3}$ (iD), Steven Doctorman ${ }^{2}$, Fan $W_{u^{2}}$ and Daniele M. Gilkes $1,2,3,4, *(D)$ \\ 1 The Sidney Kimmel Comprehensive Cancer Center, Department of Oncology, \\ The Johns Hopkins University School of Medicine, Baltimore, MD 21231, USA; ines.godet@jhu.edu \\ 2 Department of Chemical and Biomolecular Engineering, The Johns Hopkins University, \\ Baltimore, MD 21218, USA; sdoctor1@jhu.edu (S.D.); fwu30@jhu.edu (F.W.) \\ 3 Johns Hopkins Institute for NanoBioTechnology, The Johns Hopkins University, Baltimore, MD 21218, USA \\ 4 Cellular and Molecular Medicine Program, The Johns Hopkins University School of Medicine, \\ Baltimore, MD 21231, USA \\ * Correspondence: dgilkes1@jhu.edu
}

Citation: Godet, I.; Doctorman, S.; Wu, F.; Gilkes, D.M. Detection of Hypoxia in Cancer Models: Significance, Challenges, and Advances. Cells 2022, 11, 686 https://doi.org/10.3390/ cells11040686

Academic Editor: Ana Clara Carrera

Received: 17 January 2022 Accepted: 9 February 2022 Published: 16 February 2022

Publisher's Note: MDPI stays neutral with regard to jurisdictional claims in published maps and institutional affiliations.

Copyright: (C) 2022 by the authors. Licensee MDPI, Basel, Switzerland. This article is an open access article distributed under the terms and conditions of the Creative Commons Attribution (CC BY) license (https:// creativecommons.org/licenses/by/ $4.0 /)$.
Abstract: The rapid proliferation of cancer cells combined with deficient vessels cause regions of nutrient and $\mathrm{O}_{2}$ deprivation in solid tumors. Some cancer cells can adapt to these extreme hypoxic conditions and persist to promote cancer progression. Intratumoral hypoxia has been consistently associated with a worse patient prognosis. In vitro, 3D models of spheroids or organoids can recapitulate spontaneous $\mathrm{O}_{2}$ gradients in solid tumors. Likewise, in vivo murine models of cancer reproduce the physiological levels of hypoxia that have been measured in human tumors. Given the potential clinical importance of hypoxia in cancer progression, there is an increasing need to design methods to measure $\mathrm{O}_{2}$ concentrations. $\mathrm{O}_{2}$ levels can be directly measured with needletype probes, both optical and electrochemical. Alternatively, indirect, noninvasive approaches have been optimized, and include immunolabeling endogenous or exogenous markers. Fluorescent, phosphorescent, and luminescent reporters have also been employed experimentally to provide dynamic measurements of $\mathrm{O}_{2}$ in live cells or tumors. In medical imaging, modalities such as MRI and PET are often the method of choice. This review provides a comparative overview of the main methods utilized to detect hypoxia in cell culture and preclinical models of cancer.

Keywords: hypoxia; detection; cancer; HIF

\section{Introduction}

Regions of hypoxia arise in $90 \%$ of solid tumors as cancer cells quickly proliferate, and scarce, newly formed vasculature fails to supply sufficient oxygen [1]. In patients with breast cancer, the mean partial pressure of oxygen $\left(\mathrm{PO}_{2}\right)$ in breast tumors ranges from 2.5 to $28 \mathrm{mmHg}$, with a median value of $10 \mathrm{mmHg}\left(1 \% \mathrm{O}_{2}\right)$, while normal human breast tissue has a median value of $65 \mathrm{mmHg}\left(8 \% \mathrm{O}_{2}\right)$ [2]. Several studies have demonstrated that patients with hypoxic tumors have an increased risk of metastasis and mortality [3-5]. Hypoxia has been reported to be an adverse prognostic indicator, independent of clinical stage, at the time of diagnosis [6]. Cancer cells can adapt and survive under oxygen deprivation, and the most well-reported mechanism involves the hypoxia-inducible factors (HIFs) [7]. In an $\mathrm{O}_{2}$-rich environment, prolyl hydroxylases (PHDs) hydroxylate HIF- $1 \alpha$ and HIF- $2 \alpha$. The von HippelLindau (VHL) E3 ubiquitin ligase ubiquitinates hydroxylated HIF- $1 \alpha$ and HIF- $2 \alpha$ causing its proteasomal degradation [8]. In contrast, under hypoxia, HIF- $1 \alpha$ and HIF- $2 \alpha$ subunits become stabilized and bind to the HIF- $1 \beta$ subunit [9]. Both HIF-1 and HIF-2 heterodimers recognize and bind to the $5^{\prime}$-ACGTG-3' enhancer sequence, resulting in the transcriptional regulation of more than a thousand genes $[10,11]$. The abundance and activity of both HIF- $1 \alpha$ and HIF- $2 \alpha$ can also be enhanced due to post-translational modifications [12]. 
HIF-regulated genes have been associated with angiogenesis, apoptosis, cell proliferation, cell survival, metabolism, invasion, metastasis, altered $\mathrm{pH}$, and chemoresistance [5].

Hypoxia has been detected using both direct and indirect methods in cells cultured in the laboratory and animal and human tumors. Direct $\mathrm{O}_{2}$ measurements have been made in solid tumors of cancer patients using needle-type $\mathrm{O}_{2}$ electrodes [2,13-15]. Indirect methods, such as the immunolabeling of HIF-1/2 $\alpha$ or downstream HIF-targets, have been used to detect potential regions of hypoxia in fixed tissue after surgical resection or biopsy [16]. Moreover, exogenous 2-nitroimidazole probes, such as pimonidazole, can be delivered to animals or humans and incorporate into hypoxic adducts that can be immunolabeled once the tissue is harvested and fixed [17]. Immunolabeling-based methods are insightful but limited by protein turnover and fixation artifacts, and they cannot be used for realtime assessment. For preclinical studies, several groups have used DNA constructs that cause the cell to express reporters, such as fluorescent proteins or luciferase, in a HIFdependent manner as an indirect real-time readout of hypoxia [18,19]. In preclinical and clinical approaches, intratumoral $\mathrm{O}_{2}$ levels are measured in real-time, albeit indirectly, using techniques such as Magnetic Resonance Imaging (MRI) and Positron Emission Tomography (PET) [5].

Over the past two decades, multiple experimental approaches have been established to investigate hypoxia. To recreate intratumoral hypoxia in a laboratory setting, one fairly standard approach is to culture cancer cells in chambers with a controlled environment containing $1 \% \mathrm{O}_{2}$ for $24 \mathrm{~h}$ or $48 \mathrm{~h}[20,21]$. More recently, 3D models, such as spheroids or organoids, have been used to recreate spontaneous gradients of nutrients and oxygen [22]. Furthermore, murine models are a well-established approach to assess tumor growth and metastasis and also contain gradients of $\mathrm{O}_{2}$ with levels approaching less than $1 \%$ in perinecrotic regions [23-25]. As research into the role of hypoxia in cancer progression and metastasis has expanded, models to recapitulate this condition and tools to detect it have rapidly progressed.

This review article highlights well-established methods and emerging technologies to detect hypoxia in vitro, in cells and 3D models; in vivo, in tumors and live tissue; and ex vivo in tumor sections. In addition, we describe and categorize the most common methods by their application.

\section{Detection of Hypoxia In Vitro}

\subsection{Immunolabeling of Endogenous Markers}

HIF-1 $\alpha$ immunolabeling using immunohistochemical (IHC) or immunofluorescent (IF) techniques have frequently been employed to identify hypoxic cells in 2D and 3D cell culture (1 in Figure 1). In formalin-fixed, paraffin-embedded, MCF7 cell-derived spheroids cultured under $20 \% \mathrm{O}_{2}$, IHC staining of HIF- $1 \alpha$ was used to identify regions of hypoxia within the spheroid core. Likewise, Ohnishi et al. reported HIF-1 $\alpha$ staining in cells localized within the center of glioblastoma (T98G) cell-derived spheroids [26].

HIF- $1 / 2 \alpha$ immunolabeling can be challenging due to the short half-life of HIF- $1 / 2 \alpha$ proteins upon re-exposure to oxygen. Moreover, HIF- $1 \alpha$ and HIF- $2 \alpha$ are localized in the nucleus under hypoxic conditions, making nuclear permeabilization required for their detection. This has led to the use of HIF-transcriptional targets, which are more abundant or easier to immunolabel, as an alternative target for HIF immunolabelling (2 in Figure 1). Glucose transporter 1 (GLUT-1), monocarboxylate transporter 1 (MCT-1), and carbonic anhydrase IX (CA-IX) are well established HIF-target genes [27]. Under hypoxia, cancer cells switch to aerobic respiration due to the Warburg effect [28], and GLUT-1 is upregulated to facilitate glucose uptake and catalyze the transformation of pyruvate to lactate. In addition, the expression level of MCT-1 and CA-IX increases to mediate lactate efflux and maintain an acidic extracellular environment [29,30]. Studies have correlated the expression of HIF- $1 \alpha$ and downstream targets using immunolabeling to validate their use as a method to detect hypoxic cells. For instance, Miranda-Gonçalves et al. cultured glioma cells under $1 \% \mathrm{O}_{2}$ for $24 \mathrm{~h}$ or in a spheroid model and showed 
that HIF-1 $\alpha$ staining colocalized with increased GLUT-1, MCT-1, and CA-IX staining [27]. Overall, immunolabeling of HIF-1 $\alpha$ and its downstream targets can be used as a proxy to detect hypoxia in cells exposed to low $\mathrm{O}_{2}$ concentrations and to detect spontaneous $\mathrm{O}_{2}$ gradients that develop in $3 \mathrm{D}$ culture over time. The limitations are that these are indirect measurements of hypoxia, do not provide the specific $\mathrm{O}_{2}$ concentration of the tumor, cannot be performed in real-time, and require tissue or cell fixation. It is also important to remember that multiple mechanisms other than hypoxia can enhance HIF- $1 \alpha$ and HIF- $2 \alpha$ expression [31].

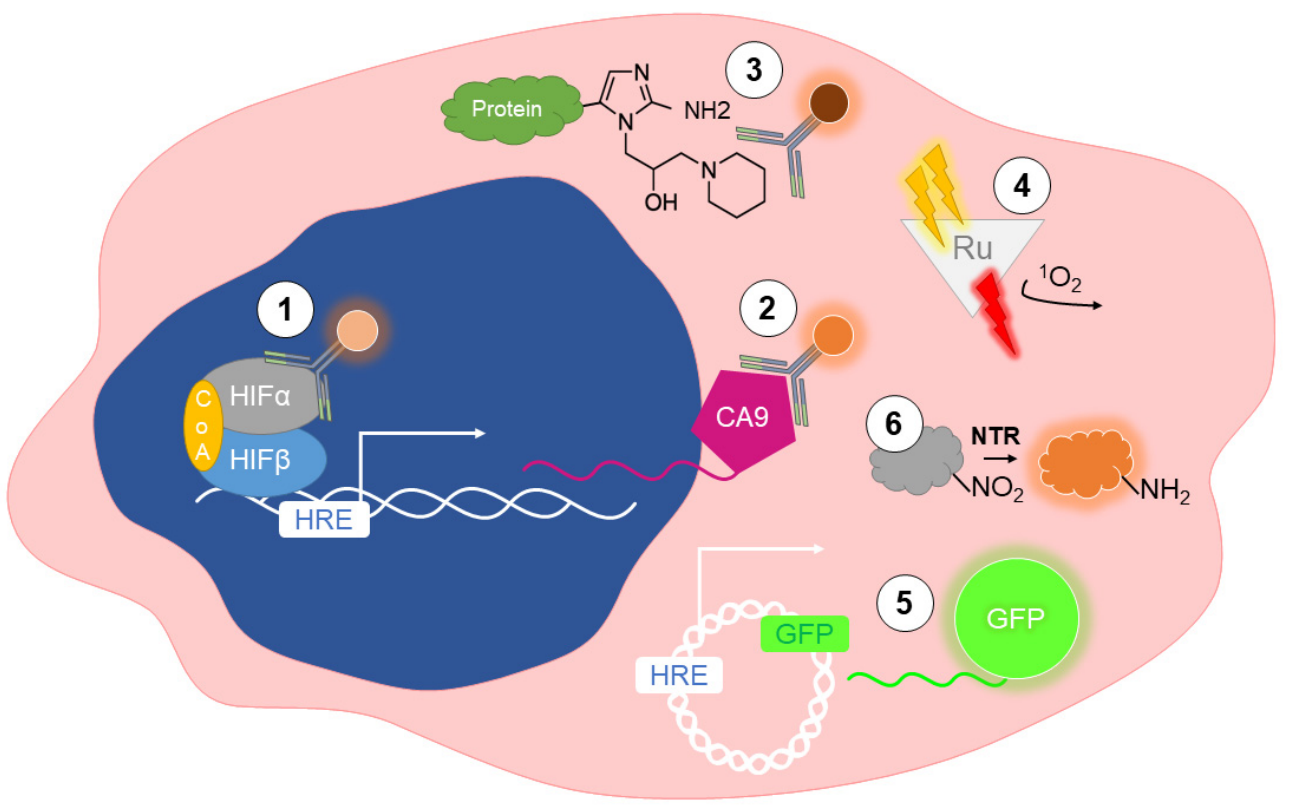

Figure 1. Detecting hypoxia in vitro. (1) Immunolabeling of HIF-1 $\alpha$ or HIF-2 $\alpha$ protein. (2) Immunolabeling of downstream transcriptional targets of HIFs (e.g., CA-IX). (3) Immunolabeling of hypoxia probes delivered exogenously $3 \mathrm{~h}$ before fixation (e.g., pimonidazole). (4) Oxygen quenches phosphorescent probes (e.g., Rubidium) after excitation with 2-photon light. (5) DNA construct is transcriptionally regulated by HIFs that express any protein (e.g., GFP) in a hypoxia-dependent manner. (6) Fluorescent molecules activated by nitroreductases (NTR) exclusively under hypoxia.

\subsection{Immunolabeling of Exogenous Markers}

Another well-established strategy to detect hypoxia is the use of exogenous markers. These probes are a class of 2-nitroimidazoles first reported to form hypoxic adducts in $\mathrm{CHO}$ cells by Varghese et al. in 1976 [32] (3 in Figure 1). Under hypoxia $\left(\mathrm{PO}_{2}<10 \mathrm{mmHg}\right.$, approximately $<1.3 \% \mathrm{O}_{2}$ ), nitroimidazole binds to macromolecules such as proteins, peptides, and amino acids, to form adducts with their thiol groups. After reducing its imidazole ring, this probe selectively accumulates in hypoxic cells. Subsequently, hypoxic cells can be visualized by introducing a tag incorporated via an antibody that specifically recognizes the metabolic product of nitroimidazole [17]. Derivatives of nitroimidazole, such as pimonidazole and EF-5, are well-established for immunolabeling. However, other derivatives such as CCI-103F and A2-nitroimidazole (NITP) are not used due to their poor solubility in water. Another nitroimidazole, Misonidazole, lacks an antibody with high enough affinity for detection $[33,34]$.

Both Pimonidazole and EF-5, and the specific antibodies designed to detect them, Hypoxyprobe $^{\mathrm{TM}}$ and ELK3-51, respectively, are commercially available and used for over 20 years (see Section 3.2). For example, Hypoxyprobe ${ }^{\mathrm{TM}}$ and ELK3-51 staining have been used to detect hypoxia in the center of 3D cell-derived spheroids cultured in the presence of pimonidazole or EF-5, respectively [35]. In summary, exogenous hypoxia markers are useful to detect hypoxia. Nevertheless, they require pre-exposure to a nitroimidazole derivative for several hours, followed by fixation and immunolabeling with an antibody 
that recognizes the nitroimidazole derivative with high specificity. Moreover, they cannot be used for real-time measurements.

\subsection{Phosphorescent Reporters}

While insightful, immunolabeling of endogenous and exogenous hypoxic markers requires a fixation step, which prevents the dynamic monitoring of hypoxia. Oxygendependent phosphorescence quenching is a direct and noninvasive method to measure $\mathrm{O}_{2}$ concentrations in live cells [36]. The phosphorescence lifetime is the average time a molecule remains in an excited state until it returns to the ground state by emitting a photon. The time is linearly dependent on the level of $\mathrm{O}_{2}$ in the microenvironment and can be converted to a measurement of partial pressure $\left(\mathrm{PO}_{2}\right)$ (4 in Figure 1) [37]. Multiple metal complexes have been used as phosphorescent probes, including $\operatorname{Ru}(\mathrm{II}), \operatorname{Ir}(\mathrm{III}), \mathrm{Pt}(\mathrm{II})$, $\operatorname{Re}(\mathrm{II})$, and Os(II) complexes, as well as metalloporphyrins with Pt(II) or Pd(II). Particularly $\mathrm{Pt}(\mathrm{II})$ and $\mathrm{Pd}(\mathrm{II})$ porphyrins and $\mathrm{Ru}(\mathrm{II})$ and $\mathrm{Ir}(\mathrm{III})$ complexes are the most established probes utilized in live systems (cell culture and animal models) [38,39]. Phosphorescent probes are often modified with lipophilic polymers and peptide ligands to increase cellular uptake [40,41], biocompatibility [42], and targeted organelle specificity [43].

Several approaches using phosphorescent lifetime probes have been established and optimized to detect $\mathrm{O}_{2}$ levels in cells. For instance, Kurokawa et al. used the phosphorescent dye, PtTCPP, to detect phosphorescence lifetime in Colon26 cells exposed to decreasing $\mathrm{O}_{2}$ concentrations (20 to $1 \% \mathrm{O}_{2}$ ) or cultured in a spheroid model, using a laser scanning confocal microscope for detection. The decrease in the phosphorescence lifetime correlated with decreasing $\mathrm{O}_{2}$ concentrations [44]. Raza et al. established a small-molecule platinum (II) complex probe ( $\mathrm{PtLsCl}$ ) to map the $\mathrm{O}_{2}$ distribution across live spheroids derived from human melanoma cell lines, validated by Hypoxyprobe ${ }^{\mathrm{TM}}$ staining [45].

Phosphorescence lifetime imaging (PLIM) typically requires a pulsed laser to excite the phosphorescent probe, a detection system to capture and quantify the emitted photons, such as a photomultiplier tube, and software to convert captured photons into a measurement of $\mathrm{PO}_{2}$. Recently, a new class of phosphorescent reporters detected using a fluorescent microscope was developed. The photophysical properties of some of these $\mathrm{O}_{2}$ sensors have been recently reviewed and go beyond the scope of this review [46,47].

At least one phosphorescent probe used to detect hypoxia has been commercialized. For example, the Image-iT ${ }^{\mathrm{TM}}$ red hypoxia reagent manufactured by Thermofisher is based on an iridium complex that can be excited with $490 \mathrm{~nm}$ light and emits at $610 \mathrm{~nm}$ wavelength [48]. This probe begins to fluoresce when $\mathrm{O}_{2}$ levels are less than $5 \%$, and the signal increases with decreasing $\mathrm{O}_{2}$. The fluorogenic response is reversible upon reoxygenation. Ilana et al. employed the Image-iT ${ }^{\mathrm{TM}}$ red hypoxia reagent to visualize and quantify hypoxia in MCF7-derived spheroids exposed to decreasing $\mathrm{O}_{2}$ levels from $20 \%$ to $1 \%$ [49]. Our study used it to image $\mathrm{O}_{2}$ gradients in murine breast tumor organoids after 11 days in culture under normal $\mathrm{O}_{2}$, which correlated with our fluorescent hypoxia fate-mapping reporter system [19]. In summary, the phosphorescent probes must be added before each measurement, allowing for short-term but real-time detection of $\mathrm{O}_{2}$ gradients.

\subsection{Fluorescent Reporters}

An alternative approach to dynamically monitor hypoxia is the incorporation of vectors that drive the production of fluorescent proteins exclusively under hypoxia. Multiple groups have developed functional vectors containing one or more copies of a hypoxiaresponsive element (HRE) located proximal to a minimal promoter, such as mCMV [50] or minTK [19] (5 in Figure 1). Incorporating an HRE causes the HIF-complex to drive the production of a protein of interest, such as GFP [19] or RFP [51], under hypoxia. The expression of such fluorescent proteins allows for the detection of hypoxic cells. However, some fluorophores require molecular $\mathrm{O}_{2}$ for proper protein folding and chromophore maturation. Moreover, while HIF- $1 / 2 \alpha$ degradation occurs within minutes upon reoxygenation, fluorescent reporters have a longer half-life $[52,53]$. To decrease the half-life of 
a reporter, destabilization elements like the PEST sequence motif (peptide sequence that promotes ubiquitination and protein degradation $)^{5}$ or the oxygen-dependent degradation domain (ODD) sequence derived from HIF-1 $\alpha$ (oxygen-dependent degradation domain) are often fused to the $\mathrm{C}$ - or $\mathrm{N}$ - terminus of the reporter to accelerate its degradation when $\mathrm{O}_{2}$ is present $[19,53,54]$. Multiple variations of these biosensors have been widely and successfully utilized to investigate hypoxia in vitro. For instance, Le et al. combined a HIF-regulated GFP-PEST reporter with a mCherry-geminin reporter to investigate the metabolic phenotypes of hypoxic and reoxygenated cells [55]. Henning et al. used a GFP hypoxia reporter to show the development of a hypoxic core in HCT116 spheroids $96 \mathrm{~h}$ after spheroid formation [54].

While these methods allow for the visualization of hypoxic cores in 3D culture, once a cell is reoxygenated, the fluorescence signal is designed to be degraded. While this is helpful for the real-time monitoring of hypoxia, tracking and isolation of reoxygenated cells is not possible. Our group developed a dual vector hypoxia fate-mapping system to track hypoxic cells even after reoxygenation to overcome this obstacle. Under hypoxia, HIF stabilization promotes the transcription of a CRE-ODD complex. CRE-ODD protein expression causes Cre-Loxp recombination resulting in the excision of any gene that is 'floxed'. We paired the HIF-CRE-ODD construct with a construct containing a floxed DsRed gene proximal to an eGFP gene. This caused the loss of DsRed expression and permanent eGFP expression under hypoxia. We transduced both MCF7 and MDA-MB-231 breast cancer cell lines with lentiviral vectors containing the two constructs. Spheroids derived from both cell lines develop spontaneous hypoxic cores over 15 days, and GFP+ cells invaded the spheroid regions with higher $\mathrm{O}_{2}$ content than the core of the spheroid $\left(1 \% \mathrm{O}_{2}\right.$ as measured with an optical needle probe (see Section 2.6). We also developed a transgenic mouse model based on this system. The organoids derived from the spontaneous tumors that the mice developed also showed hypoxic cores when they were cultured in 3D [19]. GFP expression correlated with $\mathrm{O}_{2}$ concentrations in the gel as low as $1 \%$ as measured using optical oxygen detection nanoprobes (see Section 2.5). Overall, fluorescent reporters offer a reliable but indirect method for evaluating hypoxia in vitro. Although they cannot provide a specific $\mathrm{O}_{2}$ measurement, they can be designed to fluoresce when cells experience specific $\mathrm{O}_{2}$ concentrations.

\subsection{Nitroreductase-Sensitive Fluorescent Probes}

Instead of delivering a DNA construct to drive the production of a fluorescent protein under hypoxia, some groups are testing bioreductive activators of fluorescence that trigger fluorescence in specific substrates, predominantly p-substituted aromatic nitro compounds [56]. Nitroreductases (NTRs) are enzymes expressed only under hypoxic conditions that reduce the nitro group of the substrate by converting it into an amino group, causing the substrate to fluoresce [57] (6 in Figure 1). These substrates are directly added to cell culture media for in vitro use or injected into the tail vein in murine models (see Section 3.4). Since NTR fluorescent hypoxia probes are easily incorporated in cell culture, commercial options are available. For example, BioTracker ${ }^{\mathrm{TM}} 520$ Green Hypoxia Dye by Merck can be fluorescently imaged and begins to fluoresce at $5 \% \mathrm{O}_{2}$ [58]. This probe has successfully been employed to detect hypoxia in cells cultured as 2D and 3D spheroids [59].

Overall, this approach provides an indirect fluorescent readout of hypoxia. To date, multiple NTR probes have been designed and implemented, but current efforts focus on simplifying synthesis protocols and enhancing emission wavelengths [60].

\subsection{Noninvasive Optical Oxygen Sensors}

Oxygen levels can be directly monitored during cell culture by using noninvasive $\mathrm{O}_{2}$ sensors that are placed in cell culture wells. Light-sensitive $\mathrm{O}_{2}$ sensors or dyes become excited, for instance, with blue (450-495 nm) or red light $(610-630 \mathrm{~nm})$, and either emit light at a measurably higher wavelength or are quenched by $\mathrm{O}_{2}$. The emitted light is captured, and the ratio of captured light versus the emitted light can be converted to a specific $\mathrm{O}_{2}$ 
concentration [61]. The sensors can be arranged into arrays or films inside a sticky patch or foil so that they can be easily attached to the top or bottom of a transparent tissue culture plate. For instance, Silva et al. used the planar $\mathrm{O}_{2}$ sensor foil SF-RPsSu4 in conjunction with a novel 3D-printed ramp to assess $\mathrm{O}_{2}$ levels at different heights in a single well of a 96-well plate. The authors reported that the $\mathrm{O}_{2}$ concentration at the top of a confluent well of A549 cells cultured for $96 \mathrm{~h}$ was $12.9 \% \mathrm{O}_{2}$ versus $7.5 \% \mathrm{O}_{2}$ at the surface of the cell layer, which was confirmed with a fiber-based needle microsensor [62] (see Section 2.6).

Commercial options using this approach are available. For example, Lewis et al. monitored $\mathrm{O}_{2}$ levels non-invasively by placing commercially available sensor patches manufactured by PreSens at the bottom of a tissue culture well-containing hydrogels that were incorporated with murine sarcoma (KIA) GFP-expressing cells. Three days after seeding, the authors measured $\mathrm{O}_{2}$ gradients from the surface $\left(13 \% \mathrm{O}_{2}\right)$ to the bottom $\left(4 \% \mathrm{O}_{2}\right)$ of their hypoxic gel [63]. Our studies have utilized oxygen nanoprobes (OXNANO) manufactured by Pyroscience to detect the $\mathrm{O}_{2}$ concentration within Matrigel matrices containing organoids derived for mouse breast tumors. The nanoprobes were dispersed in the Matrigel and excited by a red-light source $(610-630 \mathrm{~nm})$ using an $\mathrm{O}_{2}$ meter that collects the light emitted by the nanoprobes in the near-infrared range (760-790 nm). This technology allowed us to make daily measurements of $\mathrm{O}_{2}$ concentrations within the Matrigel and demonstrated that $\mathrm{O}_{2}$ levels declined from $15 \%$ to $1 \% \mathrm{O}_{2}$ over an 11-day time course. This correlated with larger hypoxic cores that were visualized using our fluorescent hypoxia reporter system and the Image-iT ${ }^{\mathrm{TM}}$ red hypoxia probe [19]. Noninvasive optical sensors are useful for $\mathrm{O}_{2}$ measurements because of their accessibility and relative accuracy.

\subsection{Invasive Optical Oxygen Sensors}

To determine the $\mathrm{O}_{2}$ concentration at different sites within $3 \mathrm{D}$ structures such as organoids or spheroids, invasive $\mathrm{O}_{2}$ needle probes are needed. Light-sensitive dyes can be coated onto the tip of a needle probe for this purpose (see Section 3.12) and can be used to measure $\mathrm{O}_{2}$ as described above (see Section 2.5) [64]. Our group utilized a retractable-needle fiber-optic microprobe (Pyroscience) to demonstrate that $\mathrm{O}_{2}$ levels drop from the periphery $\left(11 \% \mathrm{O}_{2}\right)$ to the core $\left(1 \% \mathrm{O}_{2}\right)$ of MDA-MB-231 spheroids encapsulated in a collagen gel after they had been cultured for 20 days. The measurement correlated with the activation of our fluorescent hypoxia reporter system and Image-i $\mathrm{T}^{\mathrm{TM}}$ red hypoxia staining [19]. Overall, while invasive probes accurately enable 3D measurements of hypoxia gradients, their invasive nature may disrupt the physical integrity of the system being tested [63].

\section{Detection of Hypoxia In Vivo}

\subsection{Immunolabeling of Endogenous Markers}

Immunolabeling of HIF- $1 \alpha$ and HIF- $2 \alpha$, and their downstream targets, are wellestablished methods used to identify regions of intratumoral hypoxia, not only in vitro as described in Section 2.1, but also in tissue sections using both IHC and IF techniques [65] (1 in Figure 2). The caveat of staining for HIFs and HIF-target gene expression is that HIFs can also be regulated by many non-canonical pathways such as nutrient deprivation, oxidative phosphorylation inhibitors, and mutations in the VHL gene [31]. 


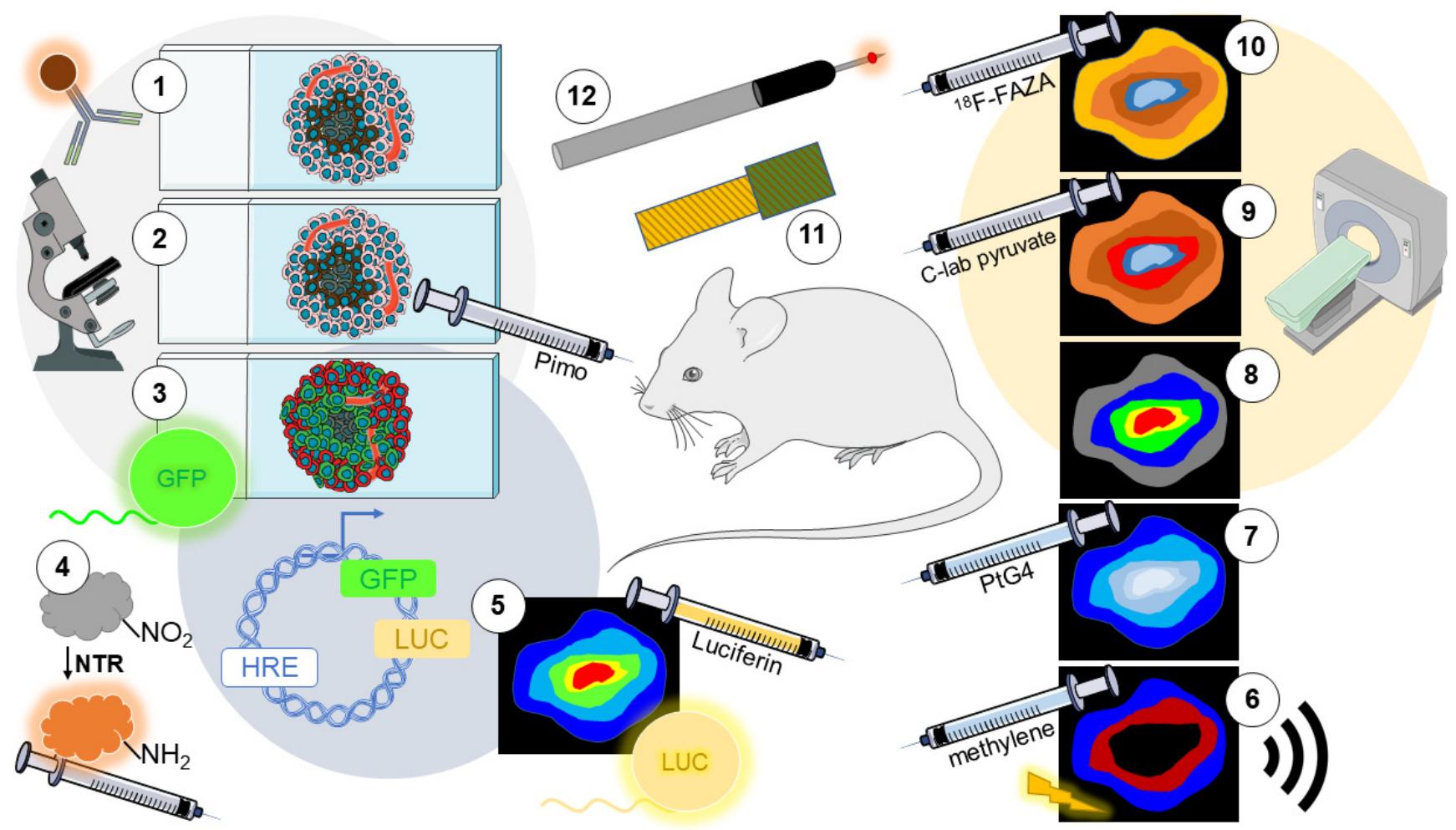

Figure 2. The detection of hypoxia in vivo. (1) Immunolabeling of endogenous hypoxia markers in tumor sections by IF/IHC. (2) Immunolabeling of exogenous hypoxia probes delivered via I.P./I.V. injection 1-2 h before sacrificing the animal (e.g., pimonidazole) in tumor sections by IF/IHC or FC of tumor-dissociated cell suspension. (3) Hypoxia-dependent fluorescent reports are expressed in cancer cells used to generate tumors. Fluorescence can be acquired using a whole animal imaging approach, tumors sections can be imaged by fluorescent microscopy, or tumor cell suspension analyzed by FC. (4) Delivery of fluorescent molecules activated by NTRs exclusively under hypoxia. (5) Hypoxia-dependent bioluminescent reporter expression in cancer cells used to generate tumors. An animal is pre-injected with luciferin and imaged using IVIS. (6) Photoacoustic signals generated by the absorption of near-infrared photons in chromophores of $\mathrm{O}_{2}$-sensitive dyes delivered to the animal cause thermoelastic expansion recordable through a transducer. (7) Imaging of an $\mathrm{O}_{2-}$ quenched phosphorescent molecule injected into the animal (e.g., PtG4) with Cherenkov-Excited Luminescence Imaging (CELI) that measures visible photons during radiotherapy. (8) Functional Magnetic Resonance Imaging (fMRI) technology that measures metabolic function via variations in oxyhemoglobin and deoxyhemoglobin ratios using blood-oxygen-level-dependent (BOLD) or tumor oxygenation level-dependent (TOLD) contrast methods. (9) Electron Paramagnetic Resonance Imaging (EPRI) is similar to MRI, but it uses an injected spin probe (e.g., C-labeled pyruvate). (10) Positron Emission Tomography (PET) is an imaging technology that uses 2-nitroimidazole radiolabeling tracers (e.g., ${ }^{18}$ F-FAZA) with computerized tomography. (11) Electrochemical oxygen sensor that can be implanted or inserted into a needle probe and detects ionization of $\mathrm{O}_{2}$ atoms via a reduction reaction at an electrode. (12) Optical invasive sensors contain an optical fiber with an $\mathrm{O}_{2}$-specific phosphorescent dye coated on the tip that, when excited, the emitted light is captured optically, and the ratio of captured over emitted light is converted to a specific $\mathrm{O}_{2}$ value.

\subsection{Immunolabeling of Exogenous Markers}

Exogenous probes, as first described in Section 2.2, can be used to detect regions of hypoxia in tissue, cells, 3D organoids, or spheroids that have been fixed. To use exogenous probes in vivo, such as pimonidazole, the probe must be injected or orally administered to the subject (animal or human). The probe causes hypoxic adducts to form that can then be detected using a probe-specific antibody by IHC or IF once the tissue has been fixed and sectioned for staining [17] (2 in Figure 2). 
Recently, probes have also been developed that do not require antibody labeling. For example, Seelam et al. used U87MG and CT-26 cells xenografted into the right shoulder of $\mathrm{BALB} / \mathrm{c}$ mice to compare two 2-nitroimidazole-fluorophore-conjugated derivatives comprised of FITC and RITC fluorophores, 1-( $3^{\prime}, 6^{\prime}$-Dihydroxy-3-oxo-3H-spiro[isobenzofuran1,9'-xanthene]-5-yl)-3-(2-(2-nitro-imidazolyl)ethyl)thiourea and 2-(3,6-Bis(diethylamino)9H-xanthan-9-yl)-5-(3-(2-(2-nitro-1H-imidazole-1-yl)ethyl)thioureido)benzoic acid, respectively, with Hypoxyprobe ${ }^{\mathrm{TM}}$ (pimonidazole- $\mathrm{HCl}$ ). After two weeks, each probe was injected intravenously with pimonidazole into mice, and tissue specimens were collected, immunolabeled for Hypoxyprobe, and imaged. The fluorescence signal from the two nitroimidazole fluorescent derivates colocalized with pimonidazole-Hypoxyprobe ${ }^{\mathrm{TM}}$ staining. Since the conjugated-derivatives have the benefit of being directly detected via fluorescence imaging ex vivo, this avoids the extra steps of immunolabeling and may offer a promising alternative to Hypoxyprobe ${ }^{\mathrm{TM}}$ immunolabeling [66]. The fluorescence stability of the FITC and RITC conjugated probes was greater than $2 \mathrm{~h}$ in vitro, suggesting that these probes could potentially be used for short-term fluorescent imaging, for instance, via intravital or whole-body fluorescence imaging.

\subsection{Fluorescent Reporters}

Cell lines that have been engineered to express a fluorescent reporter after exposure to hypoxia, as introduced in Section 2.4, can also be used to generate tumors in mice in which spontaneous hypoxic regions can be imaged (3 in Figure 2). For example, Wang et al. generated an MDA-MB-231 cell line expressing a DNA construct (GFP-5HRE-ODDmCherry) that constitutively expressed GFP but only expressed mCherry under hypoxic conditions. Using intravital imaging, the authors could dynamically image single hypoxic cells in an orthotopic tumor on a live mouse [52]. In another study, Erapaneedi et al. investigated a novel family of fluorescent reporters, UnaG, which does not require $\mathrm{O}_{2}$ for chromophore maturation and emits green fluorescence when bound to its ligand, bilirubin. This heme metabolite can be supplemented in cell culture medium [67]. To incorporate $\mathrm{O}_{2}$-dependent regulation, the authors developed a reporter construct that contained five copies of the VEGF HRE sequence to drive the hypoxia-dependent activation of UnaG. By orthotopically transplanting Gli36 reporter cells into SCID mice, the study confirmed that UnaG expression could be imaged at single-cell resolution in the brain of live mice using a cranial window [50].

The fluorescent reporters described shut down upon re-exposure to $\mathrm{O}_{2}$, for example, when a hypoxic cancer cell enters the more oxygenated bloodstream [68]. To overcome this obstacle and investigate the role of intratumoral hypoxia in metastasis, our group developed a dual vector hypoxia fate-mapping system as described in Section 2.4. In this system, cells that experience hypoxia maintain permanent eGFP expression. Our studies showed a correlation of eGFP, Hypoxyprobe ${ }^{\mathrm{TM}}$, and HIF-1 $\alpha$ expression in IF-labeled tissue sections of orthotopic tumors harvested from the mammary fat pad of mice $[19,69]$. Furthermore, the system allowed us to image and collect cells that experienced hypoxia in the primary tumor and metastasized to distant organs such as the lung and liver [19,70]. Another fatemapping approach by Vermeer et al. used a HIF- $1 \alpha$-GFP-Cre-ER fusion protein delivered with a LoxP-flanked-STOP tdTomato cassette. This system is tamoxifen-inducible such that once the Cre-ER fusion protein is stable under hypoxia, it activates permanent tdTomato expression [71]. This system was tested in HR1299-MR-derived tumors and validated by comparing the tdTomato expression with EF5 staining.

Overall, fluorescent reporters are valuable methods for long-term monitoring of hypoxia in animal models of cancer. Moreover, this approach can be optimized to respond to a range of $\mathrm{O}_{2}$ concentrations by incorporating more or less $\mathrm{O}_{2}$-dependent elements (e.g., HRE, ODD, etc.). Like immunolabeling of HIF-related proteins or nitroimidazole probes, cells expressing a fluorescent reporter can be imaged at single-cell resolution [52]. However, while immunolabeling methods will only detect cells when they are experiencing hypoxia, fluorescent reporters can be imaged live over extended times using advanced 
intravital imaging or small animal fluorescent imaging. In addition, they can be engineered to mark hypoxic cells even when they become reoxygenated. The system's downside is that distinguishing hypoxic from reoxygenated cells within the tumor typically requires the delivery of two distinct reporters.

\subsection{Nitroreductase-Sensitive Fluorescent Probes}

Fluorescent substrates activated by nitroreductase enzymes under hypoxia, as described in Section 2.5 can be delivered intravenously to murine models (4 in Figure 2). For instance, Zheng et al. developed a near-infrared (NIR) $\mathrm{Cy}-\mathrm{NO}_{2}$ fluorescent substrate that nitroreductases can activate. They tested the $\mathrm{Cy}-\mathrm{NO}_{2}$ by injecting it into mouse tumors derived from $\mathrm{H} 22$ cells. The NIR fluorescence could be imaged on a whole animal imaging device [72]. In another approach, Hettie et al. created a similar nitroreductase-activated NIR reporter, $\mathrm{NO}_{2}$-Rosol, which they tested in subcutaneous tumors derived from GBM39 glioblastoma cells. $\mathrm{NO}_{2}$-Rosol was delivered directly into the tumor, and fluorescence imaging was achieved with a CRi Maestro spectral fluorescent small animal imager. The study concluded that $\mathrm{NO}_{2}$-Rosol effectively reported intratumoral hypoxia, and its signal lasted for $90 \mathrm{~min}$, which is a significantly higher retention time than other constructs utilized in this context [73]. Overall, NTR-sensitive substrates combined with fluorescent imaging can be used for real-time monitoring, and they have high sensitivity to changes in $\mathrm{O}_{2}$ levels [74].

\subsection{Bioluminescence Imaging (BLI) Reporters}

BLI measures light emitted by a living cell expressing a vector encoding a luciferase gene. In the presence of the substrate luciferin, luciferase causes the conversion of luciferin to oxyluciferin, resulting in light emission that a detector can collect. The amount of light detected is correlated with the level of hypoxia within the tumor [75] (5 in Figure 2). Saha et al. used this technology to generate a HIF- $1 \alpha$ based reporter construct, 5 HREODD-Luc, which they transfected into MDA-MB-231 cells that were directly injected into the brain of female nude mice. After two weeks, D-luciferin was administered to each mouse, and images were acquired using a whole animal In Vivo Imaging System (IVIS). The study concluded that BLI could be detected in the hypoxic region of tumors [76]. Danhier et al. furthered this model by developing a PC3 cell line that constitutively expressed TdTomato. In addition, the cells had HIF-dependent expression of eGFP and a modified luciferase protein that contains an ODD. The bioluminescence signal was used to monitor acute hypoxia because the ODD domain caused rapid degradation of the luciferase enzyme upon reoxygenation. On the other hand, eGFP had a longer half-life and thus degraded more slowly upon reoxygenation, which allowed imaging of hypoxic cells even after reoxygenation. The combination of the bioluminescent and fluorescent reporters successfully allowed the distinction of hypoxic and post-hypoxic cells due to the difference in their half-life, which was reported to be $34 \mathrm{~min}$ and $15 \mathrm{~h}$, respectively. However, contrary to BLI, the eGFP signal can be attenuated by variations in the tissue thickness during excitation and emission [18].

Whole animal fluorescent or BL imaging provides $\mathrm{mm}$ scale resolution images [77], but BLI requires the substrate luciferin to be injected immediately before imaging. The bioluminescent signal peaks between 7 and $20 \mathrm{~min}$ and then drastically wanes after injection [78]. Moreover, to obtain an accurate readout, luciferin must be well distributed within the tumor, which might be hindered, particularly in hypoxic regions, given the lack of functional vasculature in these areas. Finally, the equipment used for imaging is costly and is generally housed in a multi-user core facility rather than a single laboratory.

\subsection{Photoacoustic Imaging (PAI)}

While fluorescent imaging can be hindered by low tissue penetration and light scattering, photoacoustic (PA) signals are generated by the absorption of near-infrared photons. PAI utilizes $\mathrm{O}_{2}$-sensitive dyes that initiate rapid thermoelastic expansion, which induces the 
propagation of sound waves recordable through a transducer to detect hypoxia via spectral absorbance differences [79] (6 in Figure 2). Shao et al. used the $\mathrm{O}_{2}$-sensitive dye methylene blue to test PAI in solid tissue using nude mice injected with LNCaP prostate cancer cells. When tumors reached 5 to $10 \mathrm{~mm}$ in diameter, the dye was injected directly into the tumor, producing images using ultrasound. The authors reported hypoxic gradients within the tumors confirmed with a needle-mounted $\mathrm{O}_{2}$ probe [80].

More recently, ratiometric PA probes have been designed, meaning the ratio between reacted and unreacted probes can be measured. For example, Knox et al. developed a reaction-based ratiometric PA probe with an N-oxide functionality that undergoes selective bioreduction by heme proteins under hypoxic conditions. This irreversible chemical reaction shifts the probe's absorbance maximum and enhances the PA signal to improve detection. To test this approach, the authors implanted 4T1 cells subcutaneously into BALB/c mice to develop 300-400 $\mathrm{mm}^{3}$ tumors, and they were able to detect hypoxic gradients at high resolution and centimeter depths [81].

Gold nanorods have also been used as PA probes (AuNRs) since they have a strong absorbance in the NIR spectrum and good biocompatibility. Umehara et al. used AuNRs that contain nitroimidazole units on their surface to identify areas of hypoxia in xenograft tumors [82]. In summary, PAI is minimally invasive, which makes it promising for future clinical use. Although it allows the identification of hypoxia at a greater tissue depth than fluorescent reporters and other optical imaging modalities, deep tissue imaging using PAI is still a challenge. To date, this technology has been used to detect human breast tumors by virtue of their hypoxic status, suggesting that $\mathrm{PAI} \mathrm{O}_{2}$ probes have the potential to be translated to the clinic and provide $\mathrm{O}_{2}$ readouts [83]. A tradeoff of this approach is the requirement for specialized probes that have to be injected into the subject.

\subsection{Cherenkov-Excited Luminescence Imaging (CELI)}

As described in Section 2.3, phosphorescent molecules such as $\mathrm{Pt}(\mathrm{II})$ and $\mathrm{Pd}(\mathrm{II})$ porphyrins and $\mathrm{Ru}(\mathrm{II})$ and $\mathrm{Ir}(\mathrm{III})$ complexes can provide dynamic monitoring of hypoxia via $\mathrm{O}_{2}$-quenching. CELI is an emerging imaging technology that measures $\mathrm{PO}_{2}$ via visible photons released during radiotherapy in conjunction with a phosphorescent probe (7 in Figure 2). One of the most well-established probes for CELI imaging is the $\mathrm{O}_{2}$-quenched dendritic molecule, PtG4. Cherenkov light generated from tissue subjected to radiation excites the phosphorescence of PtG4, and the phosphorescence decay time is a direct indicator of tissue $\mathrm{PO}_{2}[84,85]$. Cao et al. developed an implantable agarose gel probe containing PtG4, which was directly injected into subcutaneous MDA-MB-231 cell-derived tumors. Tumors were imaged during fractioned radiotherapy delivered in four daily, 5 Gy doses. The retention time of PtG4 in the agarose gel was sufficient to measure $\mathrm{pO}_{2}$ at each treatment time [84].

Overall, there are still some obstacles to overcome before CELI can be used clinically to map intratumoral hypoxia, namely the toxicity associated with $\mathrm{O}_{2}$ probes. However, implantable PtG4 gel-probes delivered at an FDA-approved dose prescribed for mice was sufficient to image hypoxia in murine tumors [84]. Therefore, the most likely use for this technology would be to incorporate it into radiotherapy protocols that some cancer patients receive as a therapy to monitor intratumoral hypoxia as a way to monitor treatment efficacy.

\subsection{Magnetic Resonance Imaging (MRI)}

MRI is a noninvasive tool first employed to evaluate hypoxia in vivo in the later 20th century [86-88]. MRI uses a combination of magnets oriented in different directions to create a magnetic field that excites protons (i.e., hydrogen nuclei). The energy released during proton relaxation is captured and can be reconstructed into 3D images with a spatial resolution of 4-100 $\mu \mathrm{m}$ [89] (8 in Figure 2). Blood-oxygen-level dependent (BOLD) functional MRI measurements rely on regional differences in blood flow [90]. Oxyhemoglobin and deoxyhemoglobin have different paramagnetic properties. Deoxygenated hemoglobin is paramagnetic, which causes magnetic distortions in the surrounding tissue, whereas 
oxygenated hemoglobin is not. Therefore, image contrast in BOLD is determined by the local concentration of deoxy to oxyhemoglobin. BOLD fMRI has been successfully utilized to map hypoxia in animal models of cancer [91]. Still, the measurement can be confounded by several biological factors, such as heterogeneous tumor tissue, low regulation of blood flow, and variations in blood vessel size [92,93].

Tumor Oxygenation Level-Dependent (TOLD) MRI is a second MRI method that has been used to investigate hypoxia by measuring the concentration of free $\mathrm{O}_{2}$ molecules in the tissue $[90,94]$. O'Conner et al. recently published a review article detailing the differences between BOLD and TOLD MRI methodologies that extends beyond the scope of the current review [90]. Recent studies have incorporated siloxane injections in conjunction with TOLD MRI techniques to create precise measures of $\mathrm{PO}_{2}$ in animal models, called Proton Imaging of Siloxanes to map Tissue Oxygen Levels (PISTOL). PISTOL was developed by Kodibagkar et al. [95] and tested in vivo to measure $\mathrm{O}_{2}$ in the rat thigh muscle to develop higher resolution and faster MRI readouts [96]. To increase resolution, magnetic resonance contrast amplification (MR-CA) nanoprobes have also been utilized in MRI scans to improve the detection of hypoxia in xenograft models. The nanoprobes have been designed to respond to tumor acidosis, a common result of hypoxia, by triggering the release of incorporated contrast agents. Tumors derived from 4T1 breast cancer cells [97] and BxPC3 pancreatic cells [98] have been used to confirm the efficacy of MR-CA nanoprobes at detecting hypoxic regions. Although these methods require access to advanced and costly equipment, intratumoral hypoxia has been successfully detected and visualized in 3D. Moreover, the noninvasive nature of MRI makes it extremely attractive for preclinical and clinical uses.

\subsection{Electron Paramagnetic Resonance Imaging (EPRI)}

EPRI is an imaging system similar to MRI. However, while MRI maps the distribution of protons, EPRI measures unpaired electron spins of diffusible $\mathrm{O}_{2}$ using an injected spin probe to measure relaxation directly (9 in Figure 2). Thus, the energy released when the two unpaired electrons of molecular $\mathrm{O}_{2}$ collide with the probe's unpaired electron is linearly proportional to the $\mathrm{O}_{2}$ concentration, allowing direct $\mathrm{PO}_{2}$ measurements [99]. EPRI probes last in the site for several months after injection, and tolerate serial imaging (over several hours), making it useful for identifying hypoxic regions in a live animal [100,101]. Furthermore, EPRI offers a sub-millimeter resolution of $\mathrm{PO}_{2}$, ensuring values can be compared between various regions of the tumor [102]. The applicability of EPRI has been evaluated using both orthotopic and transgenic murine models of breast cancer [103]. EPRI and the probe-tracer OX063 have been used to determine the effectiveness of evofosfamide to improve tumor oxygenation [101]. Moreover, the feasibility of EPRI for the detection of hypoxia was successfully assessed in mouse models of glioblastoma [104] and colon adenocarcinomas [105]. Overall, EPRI is accurate for tissue $\mathrm{O}_{2}$ imaging but limited by penetration depth $(10 \mathrm{~mm})$ and the requirement for tracer injections [106]. EPRI is an emerging technology that the FDA has not yet approved, showing promise in preclinical research.

\subsection{Positron Emission Tomography (PET)}

PET is an imaging technology that, when used in conjunction with 2-nitroimidazole radiolabeling tracers and computerized tomography $(\mathrm{CT})$, can indirectly detect hypoxia non-invasively in live animals (10 in Figure 2). PET agents are radioactive compounds quantitatively measurable through their beta-decay, which is converted into a 3D image. Intratumoral hypoxia has been detected via PET by utilizing nitroimidazole isotopes, such as ${ }^{18}$ F-fluoromisonidazole ${ }^{18} \mathrm{~F}-\mathrm{FMISO}$ and ${ }^{18} \mathrm{~F}$-EF5, which irreversibly bind to thiol groups on metabolic proteins at rates inversely proportional to $\mathrm{O}_{2}$ concentrations [107]. Hirata et al. recently reported that ${ }^{18}$ F-FMISO provides valuable prognostic data on survival and treatment response for patients with glioma and information on necrosis, vascularization, and permeability of the tumor [108]. Whereas ${ }^{18}$ F-FMISO is the traditional hypoxia 
PET tracer, other nitroimidazole radiotracers such as ${ }^{18} \mathrm{~F}$-fluoroazomycin arabinoside $\left({ }^{18} \mathrm{~F}-\mathrm{FAZA}\right)$ and ${ }^{18} \mathrm{~F}-\mathrm{HX} 4$ have been preclinically and clinically tested. For instance, Peeters et al. found that ${ }^{18} \mathrm{~F}-\mathrm{FMISO}$ and ${ }^{18} \mathrm{~F}-\mathrm{HX} 4$ showed high spatial reproducibility, while ${ }^{18} \mathrm{~F}-\mathrm{FAZA}$ and ${ }^{18} \mathrm{~F}-\mathrm{HX} 4$ displayed higher sensitivity to acute hypoxia in rat tumors [109]. Likewise, ${ }^{18}$ F-FAZA has been reported as a more promising tracer than ${ }^{18}$ F-FMISO because of its improved biodistribution and enhanced tumor-to-background ratio [110]. Furthermore, clinical studies in patients with head and neck cancers have also demonstrated that ${ }^{18} \mathrm{~F}-\mathrm{HX} 4$ has higher sensitivity and specificity, faster clearance, and shorter injectionacquisition time than ${ }^{18}$ F-FMISO [111]. Therefore, while ${ }^{18}$ F-FMISO was once the most viable option, new technological capabilities have led to multiple PET tracers.

Current research also explores the possibility for PET tracers to bind to hypoxiainduced proteins instead of thiol groups. For instance, More et al. developed an ${ }^{18}$ F-PET radiotracer based on the carbonic anhydrase inhibitor drug acetazolamide. The authors tested this approach in 4T1 and HT-29 BALB/c skin xenograft models. Unfortunately, despite its theoretical feasibility, there was little tracer uptake in the tumors [112].

One significant impediment to PET is that tracers are not solely affected by hypoxic conditions. ${ }^{18}$ F-FMISO may have variable readouts due to biomolecular factors such as glycolytic byproducts [113]. ${ }^{18}$ F-FMISO accumulation varies with the abundance of glutathione S-transferase P1. Moreover, the polarization of tumor-associated macrophages, present in 50\% of the tumor mass, can also affect uptake. M2 and M1 macrophages have higher and lower uptake of ${ }^{18} \mathrm{~F}-\mathrm{FMISO}$, respectively, compared to non-polarized M0 macrophages [114]. These conclusions were confirmed by $\mathrm{O}^{\prime} \mathrm{Neill}$ et al. who reviewed data on gross, molecular, and biological features across various cancer types [115]. A further limitation is the spatial resolution intrinsic to PET-while hypoxia can occur on the micron scale, PET is limited to 1-2 mm resolution [89]. Despite some limitations, PET is a well-established method that has been successfully utilized in the clinic to measure intratumoral hypoxia in multiple solid tumor types [116].

\subsection{Electrochemical Oxygen Sensors}

The "Clark electrode" $\mathrm{O}_{2}$ sensor developed in 1956 [117] has been considered the gold standard for $\mathrm{O}_{2}$ detection. A voltage is applied to the platinum electrode, causing $\mathrm{O}_{2}$ to be reduced on the surface of the electrode, thereby producing a measurable current directly proportional to $\mathrm{O}_{2}$ concentration [118]. Recent efforts have thus been underway to miniaturize electrochemical sensors to expand their use (11 in Figure 2). Rivas et al. recently tested a wireless, implantable Clark-type electrochemical $\mathrm{O}_{2}$ sensor in rabbits implanted in the right femoral quadricep muscle. The sensors distinguished between induced hyperoxia and hypoxia states by altering the fraction of inspired oxygen $\left(\mathrm{FiO}_{2}\right)$ that the rabbits could breathe [119]. Gray et al. used a similar Clark-like sensor placed on the serosal surface of rats to study changes in $\mathrm{O}_{2}$ concentrations and visceral tissue $\mathrm{O}_{2}$ tension during intestinal surgery. The authors reported that the miniaturized sensor was better suited to obtain accurate readings than manual needle-electrodes, which can compress vasculature in a localized area and potentially affect the blood flow. Moreover, larger areas can be measured using multiple miniaturized sensors instead of a single large Clark electrode [120]. Overall, these sensors provide an accurate option to directly detect hypoxia, but applicability in the clinic is still exclusively limited to needle-probes.

\subsection{Invasive Optical Oxygen Sensors}

Another needle-based method of measuring hypoxia in solid tumors is the use of invasive optical $\mathrm{O}_{2}$ sensors. These sensors contain an optical fiber coated with an $\mathrm{O}_{2}$-specific phosphorescent dye at the tip, as described in Section 2.6 (12 in Figure 2). Invasive optical sensors are frequently used as a precise method of confirming local $\mathrm{O}_{2}$ concentrations due to their high spatial resolution of $300 \mu \mathrm{m}$ and $0.1 \mathrm{mmHg}$ [121]. For example, fiberoptic needle microsensors have been utilized to measure $\mathrm{PO}_{2}$ levels in sarcoma [63] and pancreatic [122] murine models. Our studies also used a fixed-needle microprobe to 
measure $\mathrm{O}_{2}$ concentration as a function of penetration depth in an orthotopic tumorderived with MDA-MB-231 cells [19].

These phosphorescent probes use weak excitation light to avoid the formation of the $\mathrm{O}_{2}$ singlet, which can be toxic to the surrounding tissue [123]. Moreover, external light, poor blood circulation, and pulse rate changes can be limiting factors. However, despite some potential for improvement, invasive optical $\mathrm{O}_{2}$ sensors have been successfully used for analyzing $\mathrm{O}_{2}$ gradients across tumors due to their precision and accuracy.

\section{Discussion}

Intratumoral hypoxia has a frequent incidence in solid primary tumors and greatly contributes to tumorigenesis and metastasis. In the early 1990s, multiple studies investigated the $\mathrm{O}_{2}$ levels in solid tumors utilizing polarographic probes, such as Clark probes, that are now commercially available from companies such as Eppendorf. They established that intratumoral hypoxia is an adverse indicator for patients with cancer [5]. Since then, in vitro models that progressed from 2D monolayer cell culture to 3D cellular clusters have been used to model physiological $\mathrm{O}_{2}$ and nutrient gradients found in vivo. In vivo models faithfully reproduce the lack of vasculature and subsequent hypoxic regions in solid tumors. Although mouse models are a standard in cancer research, larger animals, such as rats [124] or rabbits [125], better resemble human scale and physiology and have been used to test $\mathrm{O}_{2}$ detection methods. Furthermore, non-human primate models have been employed to assess biosafety parameters such as the biodistribution of radioactive hypoxia tracers for PET imaging [126] or to determine the effect of BOLD signal on neural activity [127]. As the relevance of intratumoral hypoxia increased, methods to assess $\mathrm{O}_{2}$ levels both in vitro and in vivo became critical.

The selection of adequate methods to monitor $\mathrm{O}_{2}$ levels in experimental set-ups must take several factors into account, namely whether they can be performed in live animals or cells versus fixed tissues and the scale and sensitivity of the measurement. To facilitate comparison across the different methods described in this review, we categorized the techniques according to a series of features that we consider relevant and their applicability in different experimental settings (Table 1). A method can be selected to fit the scientific question or the available resources. 
Table 1. Compilation of methods to detect hypoxia. Partially adapted from $[79,128]$. $Y=$ Yes; $N=$ No; NA = Not Applicable; $+/-=$ positive-negative readout LM = Light Microscopy; FM = Fluorescent Microscopy; FC = Flow Cytometry; Temp = Temporal; Res = Resolution; Non-Inv = non-invasive.

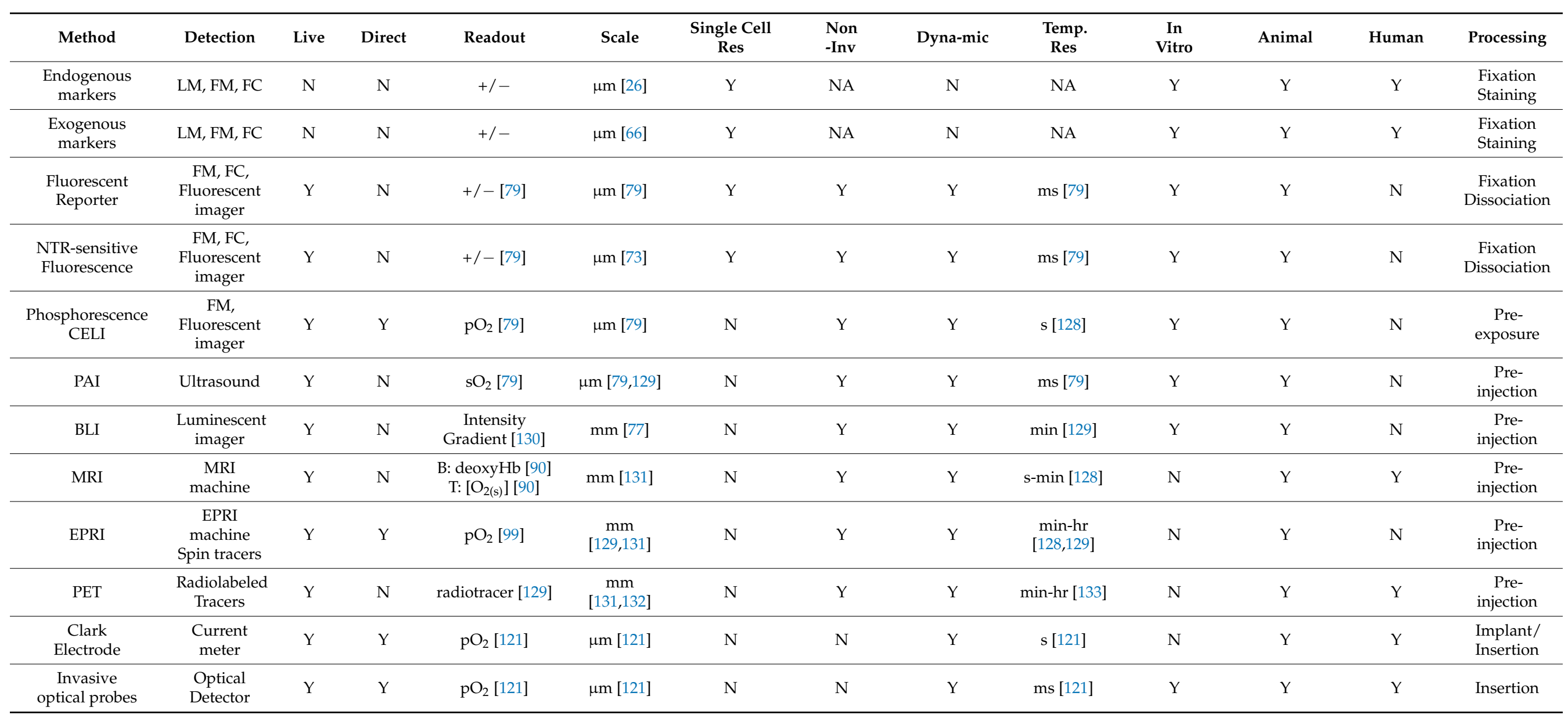


While $\mathrm{O}_{2}$-electrode or optical probes provide an accurate readout in situ, alternative methods have been established to overcome the need for an invasive approach to assess deeper tumors and preserve tissue integrity. Immunolabeling of hypoxia-regulated proteins in tissue sections has been extensively optimized to be performed in vitro and has also been employed in the clinic by staining human pathological specimens [134,135]. This particular approach is limited by rapid protein turnover and potential cross-regulation of these target proteins via mechanisms other than hypoxia. Another multifaceted approach requires the delivery of 2-nitroimidazole probes such as pimonidazole, which can be detected exclusively in hypoxic cells by immunolabeling. This method can be applied to basic cell culture or animal and human tissue sections [136]. However, immunolabeling techniques can only allow imaging of hypoxic regions when the tissue is resected and processed. Moreover, the staining is usually performed in a small portion of harvested and fixed tissue, which might not represent the entire tumor, particularly in the case of a human biopsy.

Phosphorescent and nitroreductase-regulated fluorescent probes are an easy-to-implement alternative to investigate dynamic changes in hypoxia. These probes can be added to cell culture medium or delivered to the animal intravenously to be immediately measured. This feature makes them readily marketable, and several options are available commercially. Basic scientists have taken advantage of transcriptionally regulated fluorescent, and luminescent reporters to monitor the dynamics of hypoxic and reoxygenated cancer cells. These approaches require extensive design and optimization, which can be time-consuming. However, fluorescent markers have allowed us to isolate hypoxic and reoxygenated cells to begin to unravel their contribution to tumor progression and metastatic spread.

Recent advances in medical imaging have optimized imaging modalities such as MRI and PET to specifically detect $\mathrm{O}_{2}$ levels in a tumor. Basic scientists have kept up with these advances by utilizing these methods in preclinical models. Furthermore, in murine models, whole-body imaging has been extensively employed by utilizing BLI and PAI to enable time course studies in live animals. Although whole-body imaging allows dynamic monitoring of intratumoral hypoxia throughout long time-course experiments and better resembles clinical methods, the low spatial resolution prevents single-cell tracing.

Recently, promising efforts have been made to improve $\mathrm{O}_{2}$ resolution and measure actual $\mathrm{PO}_{2}$ levels using PET. Furthermore, both CELI and EPRI are high $\mathrm{O}_{2}$-resolution $\left(\mathrm{PO}_{2}\right)$ emerging technologies with clinical potential that are currently being optimized to obtain FDA approval. In summary, whole-body imaging methods allow dynamic monitoring of $\mathrm{O}_{2}$ levels in mice and are the most promising path for clinical use, but lower spatial and oxygen resolution or access to specialized high-cost equipment are limiting factors in preclinical research. Currently, PET offers the safest and cost-efficient option to be implemented in the clinic.

Hypoxia is a condition studied across multiple research fields, particularly in the context of developmental biology with focus on embryogenesis [137]. Aside from cancer, hypoxia also plays pathophysiological roles in myocardial ischemia, metabolic diseases, chronic heart and kidney diseases, and in reproductive disorders [138]. Although significant efforts have been conducted to detect and monitor hypoxic $\mathrm{O}_{2}$ levels experimentally, it is still challenging. Many of the described methods are only a proxy for actual levels of $\mathrm{O}_{2}$, can be challenging to adapt, or require access to specialized equipment. However, current techniques have been critical in establishing findings that have impacted the field of cancer research, namely: (1) the prognostic value of intratumoral hypoxia; (2) the hypoxicupregulation of cancer hallmarks such as metabolism, migration, and chemoresistance; and (3) the significant contribution of cells that experienced intratumoral hypoxia to metastasis. As the role of hypoxia in cancer progression and resistance becomes more defined, multiple therapeutic approaches are being investigated pre-clinically and in clinical trials $[139,140]$. Thus, there is an urgent need to standardize methods to detect intratumoral hypoxia to (1) aid treatment decision and (2) assess whether hypoxia-targeted therapies perform as designed. The ultimate goal of this review is to aid researchers in selecting a suitable 
method to detect hypoxia in their studies by providing a side-by-side comparison across the most well-established and most recently optimized methods.

Author Contributions: Conceptualization, I.G. and D.M.G.; writing-original draft preparation, I.G., S.D., F.W.; writing-review and editing, I.G., S.D. and D.M.G.; supervision, D.M.G.; funding acquisition, D.M.G. All authors have read and agreed to the published version of the manuscript.

Funding: Research in the Gilkes lab is funded by NCI grant number U54-CA210173; The Jayne Koskinas Ted Giovanis Foundation for Health and Policy; Cindy Rosencrans Fund for Metastatic Triple Negative Breast Cancer; and the NCI/SKCCC Core grant number P50CA006973.

Acknowledgments: The authors would like to acknowledge Bryan Yi and Harsh Oza for preliminary research for this review article. The authors also wish to acknowledge many of the scientists that have contributed to this field, but whose work was not featured in this review due to space constraints. Cartoons included in this work's figures were adapted from Servier Medical Art licensed under a Creative Commons Attribution 3.0 Unported License (smart.servier.com, accessed on 18 December 2021).

Conflicts of Interest: The authors declare no conflict of interest.

$\begin{array}{ll}\text { Abbreviations } \\ \text { MRI } & \text { Magnetic Resonance Imaging } \\ \text { PET } & \text { Positron Emission Tomography } \\ \text { HIF } & \text { Hypoxia-Inducible Factor } \\ \text { VHL } & \text { Von Hippel-Lindau } \\ \text { IHC } & \text { Immunohistochemical } \\ \text { IF } & \text { Immunofluorescent } \\ \text { GLUT-1 } & \text { Glucose Transporter 1 } \\ \text { MCT-1 } & \text { Monocarboxylate Transporter 1 } \\ \text { CA-IX } & \text { Carbonic Anhydrase IX } \\ \text { NITP } & \text { A2-Nitroimidazole } \\ \text { PO } 2 & \text { O2 Partial Pressure } \\ \text { PLIM } & \text { Phosphorescence Lifetime Imaging } \\ \text { HRE } & \text { Hypoxia-Responsive Element } \\ \text { ODD } & \text { Oxygen-Dependent Degradation } \\ \text { NTR } & \text { Nitroreductase } \\ \text { NIR } & \text { Near-Infrared } \\ \text { BLI } & \text { Bioluminescent Imaging } \\ \text { PAI } & \text { Photoacoustic Imaging } \\ \text { PA } & \text { Photoacoustic } \\ \text { AuNR } & \text { Gold Nanorod } \\ \text { CELI } & \text { Cherenkov-Excited Luminescence Imaging } \\ \text { BOLD } & \text { Blood-Oxygen-Level Dependent } \\ \text { TOLD } & \text { Tumor Oxygenation Level-Dependent } \\ \text { PISTOL } & \text { Proton Imaging of Siloxanes to map Tissue Oxygen Levels } \\ \text { MR-CA } & \text { Magnetic Resonance Contrast Amplification } \\ \text { EPRI } & \text { Electron Paramagnetic Resonance Imaging } \\ \text { 18F-FMISO } & \text { 18F-fluoromisonidazole } \\ \text { 18F-FAZA } & \text { 18F-fluoroazomycin arabinoside } \\ \text { fMRI } & \text { Functional Magnetic Resonance Imaging } \\ & \end{array}$

\section{References}

1. Cosse, J.-P. Tumour Hypoxia Affects the Responsiveness of Cancer Cells to Chemotherapy and Promotes Cancer Progression. Anti-Cancer Agents Med. Chem. 2008, 8, 790-797. [CrossRef] [PubMed]

2. Vaupel, P.; Höckel, M.; Mayer, A. Detection and Characterization of Tumor Hypoxia Using $\mathrm{pO}_{2}$ Histography. Antioxid. Redox Signal 2007, 9, 1221-1236. [CrossRef] [PubMed]

3. Vaupel, P.; Mayer, A.; Briest, S.; Höckel, M. Oxygenation gain factor: A novel parameter characterizing the association between hemoglobin level and the oxygenation status of breast cancers. Cancer Res. 2003, 63, 7634-7637. [PubMed] 
4. Vaupel, P.; Mayer, A. Hypoxia in cancer: Significance and impact on clinical outcome. Cancer Metastasis Rev. 2007, 26, 225-239. [CrossRef]

5. Walsh, J.C.; Lebedev, A.; Aten, E.; Madsen, K.; Marciano, L.; Kolb, H.C. The Clinical Importance of Assessing Tumor Hypoxia: Relationship of Tumor Hypoxia to Prognosis and Therapeutic Opportunities. Antioxid. Redox Signal. 2014, 21, 1516-1554. [CrossRef]

6. Vaupel, P.; Mayer, A.; Höckel, M. Tumor Hypoxia and Malignant Progression. Methods Enzymol. 2004, 381, 335-354. [CrossRef]

7. Dengler, V.L.; Galbraith, M.; Espinosa, J.M. Transcriptional regulation by hypoxia inducible factors. Crit. Rev. Biochem. Mol. Biol. 2014, 49, 1-15. [CrossRef]

8. Kaelin, W.G., Jr.; Ratcliffe, P.J. Oxygen Sensing by Metazoans: The Central Role of the HIF Hydroxylase Pathway. Mol. Cell 2008, 30, 393-402. [CrossRef]

9. Jiang, B.-H.; Rue, E.; Wang, G.L.; Roe, R.; Semenza, G.L. Dimerization, DNA Binding, and Transactivation Properties of Hypoxia-inducible Factor 1. J. Biol. Chem. 1996, 271, 17771-17778. [CrossRef]

10. Wang, G.L.; Semenza, G.L. Purification and Characterization of Hypoxia-inducible Factor. J. Biol. Chem. 1995, $270,1230-1237$. [CrossRef]

11. Ye, I.C.; Fertig, E.J.; Digiacomo, J.W.; Considine, M.; Godet, I.; Gilkes, D.M. Molecular Portrait of Hypoxia in Breast Cancer: A Prognostic Signature and Novel HIF-Regulated Genes. Mol. Cancer Res. 2018, 16, 1889-1901. [CrossRef] [PubMed]

12. Daly, L.A.; Brownridge, P.J.; Batie, M.; Rocha, S.; Sée, V.; Eyers, C.E. Oxygen-dependent changes in binding partners and post-translational modifications regulate the abundance and activity of HIF-1 $\alpha / 2 \alpha$. Sci. Signal. 2021, 14, 6685. [CrossRef] [PubMed]

13. Höckel, M.; Knoop, C.; Schlenger, K.; Vorndran, B.; Baußnann, E.; Mitze, M.; Knapstein, P.G.; Vaupel, P. Intratumoral pO 2 predicts survival in advanced cancer of the uterine cervix. Radiother. Oncol. 1993, 26, 45-50. [CrossRef]

14. Hopf, H.W.; Hunt, T.K. Comparison of Clark Electrode and Optode for Measurement of Tissue Oxygen Tension. Adv. Exp. Med. Biol. 1994, 345, 841-847. [CrossRef]

15. Nordsmark, M.; Bentzen, S.M.; Overgaard, J. Measurement of Human Tumour Oxygenation Status by a Polarographic Needle Electrode: An analysis of inter- and intratumour heterogeneity. Acta Oncol. 1994, 33, 383-389. [CrossRef] [PubMed]

16. Ambrosetti, D.; Dufies, M.; Dadone, B.; Durand, M.; Borchiellini, D.; Amiel, J.; Pouyssegur, J.; Rioux-Leclercq, N.; Pages, G.; Burel-Vandenbos, F.; et al. The two glycolytic markers GLUT1 and MCT1 correlate with tumor grade and survival in clear-cell renal cell carcinoma. PLoS ONE 2018, 13, e0193477. [CrossRef]

17. Varia, M.A.; Calkins-Adams, D.P.; Rinker, L.H.; Kennedy, A.S.; Novotny, D.B.; Fowler, W.C.; Raleigh, J.A. Pimonidazole: A Novel Hypoxia Marker for Complementary Study of Tumor Hypoxia and Cell Proliferation in Cervical Carcinoma. Gynecol. Oncol. 1998, 71, 270-277. [CrossRef]

18. Danhier, P.; Krishnamachary, B.; Bharti, S.; Kakkad, S.; Mironchik, Y.; Bhujwalla, Z.M. Combining Optical Reporter Proteins with Different Half-lives to Detect Temporal Evolution of Hypoxia and Reoxygenation in Tumors. Neoplasia 2015, 17, 871-881. [CrossRef]

19. Godet, I.; Shin, Y.J.; Ju, J.A.; Ye, I.C.; Wang, G.; Gilkes, D.M. Fate-mapping post-hypoxic tumor cells reveals a ROS-resistant phenotype that promotes metastasis. Nat. Commun. 2019, 10, 4862. [CrossRef]

20. Ju, J.A.; Godet, I.; Ye, I.C.; Byun, J.; Jayatilaka, H.; Lee, S.J.; Xiang, L.; Samanta, D.; Lee, M.H.; Wu, P.-H.; et al. Hypoxia Selectively Enhances Integrin $\alpha 5 \beta 1$ Receptor Expression in Breast Cancer to Promote Metastasis. Mol. Cancer Res. 2017, 15, 723-734. [CrossRef]

21. Ju, J.A.; Godet, I.; DiGiacomo, J.W.; Gilkes, D.M. RhoB is regulated by hypoxia and modulates metastasis in breast cancer. Cancer Rep. 2020, 3, e1164. [CrossRef] [PubMed]

22. Jensen, C.; Teng, Y. Is It Time to Start Transitioning From 2D to 3D Cell Culture? Front. Mol. Biosci. 2020, 7, 33. [CrossRef] [PubMed]

23. Sobhanifar, S.; Aquino-Parsons, C.; Stanbridge, E.J.; Olive, P. Reduced Expression of Hypoxia-Inducible Factor-1 $\alpha$ in Perinecrotic Regions of Solid Tumors. Cancer Res. 2005, 65, 7259-7266. [CrossRef] [PubMed]

24. Ishii, A.; Kimura, T.; Sadahiro, H.; Kawano, H.; Takubo, K.; Suzuki, M.; Ikeda, E. Histological Characterization of the Tumorigenic "Peri-Necrotic Niche" Harboring Quiescent Stem-Like Tumor Cells in Glioblastoma. PLoS ONE 2016, 11, e0147366. [CrossRef]

25. Grimes, D.R.; Jansen, M.; Macauley, R.J.; Scott, J.G.; Basanta, D. Evidence for hypoxia increasing the tempo of evolution in glioblastoma. Br. J. Cancer 2020, 123, 1562-1569. [CrossRef]

26. Ohnishi, K.; Tani, T.; Bando, S.-I.; Kubota, N.; Fujii, Y.; Hatano, O.; Harada, H. Plastic induction of CD133AC133-positive cells in the microenvironment of glioblastoma spheroids. Int. J. Oncol. 2014, 45, 581-586. [CrossRef]

27. Miranda-Gonçalves, V.; Granja, S.; Martinho, O.; Honavar, M.; Pojo, M.; Costa, B.M.; Pires, M.M.; Pinheiro, C.; Cordeiro, M.; Bebiano, G.; et al. Hypoxia-mediated upregulation of MCT1 expression supports the glycolytic phenotype of glioblastomas. Oncotarget 2016, 7, 46335-46353. [CrossRef]

28. Liberti, M.V.; Locasale, J.W. The Warburg Effect: How Does it Benefit Cancer Cells? Trends Biochem. Sci. 2016, 41, 211-218. [CrossRef]

29. Semenza, G.L. Regulation of cancer cell metabolism by hypoxia-inducible factor 1. Semin. Cancer Biol. 2009, 19, 12-16. [CrossRef]

30. Halestrap, A.P.; Wilson, M.C. The monocarboxylate transporter family-Role and regulation. IUBMB Life 2011, 64, 109-119. [CrossRef] 
31. Iommarini, L.; Porcelli, A.M.; Gasparre, G.; Kurelac, I. Non-Canonical Mechanisms Regulating Hypoxia-Inducible Factor 1 Alpha in Cancer. Front. Oncol. 2017, 7, 286. [CrossRef] [PubMed]

32. Varghese, A.J.; Gulyas, S.; Mohindra, J.K. Hypoxia-dependent reduction of 1-(2-nitro-1-imidazolyl)-3-methoxy-2-propanol by Chinese hamster ovary cells and KHT tumor cells in vitro and in vivo. Cancer Res. 1976, 36, 3761-3765.

33. Webster, L.; Hodgkiss, R.J.; Wilson, G.D. Simultaneous triple staining for hypoxia, proliferation, and DNA content in murine tumours. Cytometry 1995, 21, 344-351. [CrossRef]

34. Hodgkiss, R.J.; Stratford, M.R.; Dennis, M.F.; Hill, S.A. Pharmacokinetics and binding of the bioreductive probe for hypoxia, NITP: Effect of route of administration. Br. J. Cancer 1995, 72, 1462-1468. [CrossRef] [PubMed]

35. Laurent, J.; Frongia, C.; Cazales, M.; Mondesert, O.; Ducommun, B.; Lobjois, V. Multicellular tumor spheroid models to explore cell cycle checkpoints in 3D. BMC Cancer 2013, 13, 73. [CrossRef]

36. Lo, L.-W.; Koch, C.J.; Wilson, D.F. Calibration of Oxygen-Dependent Quenching of the Phosphorescence of Pd-meso-tetra (4-Carboxyphenyl) Porphine: A Phosphor with General Application for Measuring Oxygen Concentration in Biological Systems. Anal. Biochem. 1996, 236, 153-160. [CrossRef] [PubMed]

37. Liu, Y.; Gu, Y.; Yuan, W.; Zhou, X.; Qiu, X.; Kong, M.; Wang, Q.; Feng, W.; Li, F. Quantitative Mapping of Liver Hypoxia in Living Mice Using Time-Resolved Wide-Field Phosphorescence Lifetime Imaging. Adv. Sci. 2020, 7, 1902929. [CrossRef] [PubMed]

38. Yoshihara, T.; Hirakawa, Y.; Hosaka, M.; Nangaku, M.; Tobita, S. Oxygen imaging of living cells and tissues using luminescent molecular probes. J. Photochem. Photobiol. C Photochem. Rev. 2017, 30, 71-95. [CrossRef]

39. Cao, X.; Allu, S.R.; Jiang, S.; Jia, M.; Gunn, J.R.; Yao, C.; LaRochelle, E.P.; Shell, J.R.; Bruza, P.; Gladstone, D.J.; et al. Tissue pO 2 distributions in xenograft tumors dynamically imaged by Cherenkov-excited phosphorescence during fractionated radiation therapy. Nat. Commun. 2020, 11, 573. [CrossRef]

40. Lee, Y.-E.K.; Ulbrich, E.E.; Kim, G.; Hah, H.; Strollo, C.; Fan, W.; Gurjar, R.; Koo, S.; Kopelman, R. Near Infrared Luminescent Oxygen Nanosensors with Nanoparticle Matrix Tailored Sensitivity. Anal. Chem. 2010, 82, 8446-8455. [CrossRef]

41. Komatsu, H.; Yoshihara, K.; Yamada, H.; Kimura, Y.; Son, A.; Nishimoto, S.-I.; Tanabe, K. Ruthenium Complexes with Hydrophobic Ligands That Are Key Factors for the Optical Imaging of Physiological Hypoxia. Chem.—A Eur. J. 2013, 19, 1971-1977. [CrossRef]

42. Wang, X.-H.; Peng, H.-S.; Cheng, K.; Liu, X.-M.; Liu, Y.-A.; Yang, W. Two-photon oxygen nanosensors based on a conjugated fluorescent polymer doped with platinum porphyrins. Methods Appl. Fluoresc. 2018, 6, 035008. [CrossRef] [PubMed]

43. Martin, A.; Byrne, A.; Burke, C.S.; Forster, R.J.; Keyes, T.E. Peptide-Bridged Dinuclear Ru(II) Complex for Mitochondrial Targeted Monitoring of Dynamic Changes to Oxygen Concentration and ROS Generation in Live Mammalian Cells. J. Am. Chem. Soc. 2014 136, 15300-15309. [CrossRef] [PubMed]

44. Kurokawa, H.; Ito, H.; Inoue, M.; Tabata, K.; Sato, Y.; Yamagata, K.; Kizaka-Kondoh, S.; Kadonosono, T.; Yano, S.; Inoue, M.; et al High resolution imaging of intracellular oxygen concentration by phosphorescence lifetime. Sci. Rep. 2015, 5, 10657. [CrossRef] [PubMed]

45. Raza, A.; Colley, H.E.; Baggaley, E.; Sazanovich, I.V.; Green, N.H.; Weinstein, J.A.; Botchway, S.W.; MacNeil, S.; Haycock, J.W. Oxygen Mapping of Melanoma Spheroids using Small Molecule Platinum Probe and Phosphorescence Lifetime Imaging Microscopy. Sci. Rep. 2017, 7, 10743. [CrossRef]

46. Chelushkin, P.S.; Shakirova, J.R.; Kritchenkov, I.S.; Baigildin, V.A.; Tunik, S.P. Phosphorescent NIR emitters for biomedicine: Applications, advances and challenges. Dalton Trans. 2021, 51, 1257-1280. [CrossRef]

47. Borisov, S.M. Fundamentals of Quenched Phosphorescence $\mathrm{O}_{2}$ Sensing and Rational Design of Sensor Materials. In Detection Science; Royal Society of Chemistry: London, UK, 2018; pp. 1-18.

48. Zhang, S.; Hosaka, M.; Yoshihara, T.; Negishi, K.; Iida, Y.; Tobita, S.; Takeuchi, T. Phosphorescent Light-Emitting Iridium Complexes Serve as a Hypoxia-Sensing Probe for Tumor Imaging in Living Animals. Cancer Res. 2010, 70, 4490-4498. [CrossRef]

49. Fridman, I.B.; Ugolini, G.S.; VanDelinder, V.; Cohen, S.; Konry, T. High throughput microfluidic system with multiple oxygen levels for the study of hypoxia in tumor spheroids. Biofabrication 2021, 13, 035037. [CrossRef]

50. Erapaneedi, R.; Belousov, V.V.; Schäfers, M.; Kiefer, F. A novel family of fluorescent hypoxia sensors reveal strong heterogeneity in tumor hypoxia at the cellular level. EMBO J. 2015, 35, 102-113. [CrossRef]

51. Almoustafa, H.A.; Alshawsh, M.A.; Chik, Z. Targeted polymeric nanoparticle for anthracycline delivery in hypoxia-induced drug resistance in metastatic breast cancer cells. Anti-Cancer Drugs 2021, 32, 745-754. [CrossRef]

52. Wang, Y.; Wang, H.; Li, J.; Entenberg, D.; Xue, A.; Wang, W.; Condeelis, J. Direct visualization of the phenotype of hypoxic tumor cells at single cell resolution in vivo using a new hypoxia probe. IntraVital 2016, 5, e1187803. [CrossRef]

53. Coralli, C.; Cemazar, M.; Kanthou, C.; Tozer, G.M.; Dachs, G.U. Limitations of the reporter green fluorescent protein under simulated tumor conditions. Cancer Res. 2001, 61, 4784-4790.

54. Karlsson, H.; Fryknäs, M.; Larsson, R.; Nygren, P. Loss of cancer drug activity in colon cancer HCT-116 cells during spheroid formation in a new 3-D spheroid cell culture system. Exp. Cell Res. 2012, 318, 1577-1585. [CrossRef] [PubMed]

55. Le, A.; Stine, Z.E.; Nguyen, C.; Afzal, J.; Sun, P.; Hamaker, M.; Siegel, N.M.; Gouw, A.; Kang, B.-H.; Yu, S.-H.; et al. Tumorigenicity of hypoxic respiring cancer cells revealed by a hypoxia-cell cycle dual reporter. Proc. Natl. Acad. Sci. USA 2014, 111, 12486-12491. [CrossRef] [PubMed]

56. James, A.; Perry, J.; Jay, C.; Monget, D.; Rasburn, J.; Gould, F. Fluorogenic substrates for the detection of microbial nitroreductases. Lett. Appl. Microbiol. 2001, 33, 403-408. [CrossRef] [PubMed] 
57. Yang, D.; Tian, H.Y.; Zang, T.N.; Li, M.; Zhou, Y.; Zhang, J.F. Hypoxia imaging in cells and tumor tissues using a highly selective fluorescent nitroreductase probe. Sci. Rep. 2017, 7, 9174. [CrossRef] [PubMed]

58. Piao, W.; Tsuda, S.; Tanaka, Y.; Maeda, S.; Liu, F.; Takahashi, S.; Kushida, Y.; Komatsu, T.; Ueno, T.; Terai, T.; et al. Development of Azo-Based Fluorescent Probes to Detect Different Levels of Hypoxia. Angew. Chem. Int. Ed. 2013, 52, 13028-13032. [CrossRef]

59. Tanaka, Y.; Nishikawa, M.; Mizukami, Y.; Kusamori, K.; Ogino, Y.; Nishimura, S.; Shimizu, K.; Konishi, S.; Takahashi, Y.; Takakura, Y. Control of polarization and tumoricidal activity of macrophages by multicellular spheroid formation. J. Control. Release 2018, 270, 177-183. [CrossRef]

60. Jiao, S.; Yang, S.; Meng, X.; Wang, C. One step synthesis of red-emitting fluorescence turn-on probe for nitroreductase and its application to bacterial detection and oral cancer cell imaging. Spectrochim. Acta Part A Mol. Biomol. Spectrosc. 2020, $241,118637$. [CrossRef]

61. Wolff, P.; Heimann, L.; Liebsch, G.; Meier, R.J.; Gutbrod, M.; van Griensven, M.; Balmayor, E.R. Oxygen-distribution within 3-D collagen I hydrogels for bone tissue engineering. Mater. Sci. Eng. C 2019, 95, 422-427. [CrossRef]

62. Silva, C.J.P.; Liebsch, G.; Meier, R.J.; Gutbrod, M.S.; Balmayor, E.R.; Van Griensven, M. A New Non-invasive Technique for Measuring 3D-Oxygen Gradients in Wells During Mammalian Cell Culture. Front. Bioeng. Biotechnol. 2020, 8, 595. [CrossRef] [PubMed]

63. Lewis, D.M.; Park, K.M.; Tang, V.; Xu, Y.; Pak, K.; Eisinger-Mathason, T.S.K.; Simon, M.C.; Gerecht, S. Intratumoral oxygen gradients mediate sarcoma cell invasion. Proc. Natl. Acad. Sci. USA 2016, 113, 9292-9297. [CrossRef] [PubMed]

64. McDonald, R.C. Development of a $\mathrm{pO}_{2}$ Guided Fine Needle Tumor Biopsy Device. J. Med Devices 2021, 16, 021003. [CrossRef] [PubMed]

65. Talks, K.L.; Turley, H.; Gatter, K.C.; Maxwell, P.; Pugh, C.; Ratcliffe, P.; Harris, A.L. The Expression and Distribution of the Hypoxia-Inducible Factors HIF- $1 \alpha$ and HIF- $2 \alpha$ in Normal Human Tissues, Cancers, and Tumor-Associated Macrophages. Am. J. Pathol. 2000, 157, 411-421. [CrossRef]

66. Seelam, S.R.; Hong, M.K.; Lee, Y.-S.; Jeong, J.M. Comparative study of 2-nitroimidazole-fluorophore-conjugated derivatives with pimonidazole for imaging tumor hypoxia. J. Radiopharm. Mol. Probes 2019, 5, 101-112. [CrossRef]

67. Kumagai, A.; Ando, R.; Miyatake, H.; Greimel, P.; Kobayashi, T.; Hirabayashi, Y.; Shimogori, T.; Miyawaki, A. A BilirubinInducible Fluorescent Protein from Eel Muscle. Cell 2013, 153, 1602-1611. [CrossRef]

68. Fares, J.; Fares, M.Y.; Khachfe, H.H.; Salhab, H.A.; Fares, Y. Molecular principles of metastasis: A hallmark of cancer revisited. Signal Transduct. Target. Ther. 2020, 5, 28. [CrossRef]

69. Rocha, H.L.; Godet, I.; Kurtoglu, F.; Metzcar, J.; Konstantinopoulos, K.; Bhoyar, S.; Gilkes, D.M.; Macklin, P. A persistent invasive phenotype in post-hypoxic tumor cells is revealed by fate mapping and computational modeling. iScience 2021, $24,102935$. [CrossRef]

70. Godet, I.; Mamo, M.; Thurnheer, A.; Rosen, D.M.; Gilkes, D.M. Post-Hypoxic Cells Promote Metastatic Recurrence after Chemotherapy Treatment in TNBC. Cancers 2021, 13, 5509. [CrossRef]

71. Vermeer, J.A.F.; Ient, J.; Markelc, B.; Kaeppler, J.; Barbeau, L.M.O.; Groot, A.J.; Muschel, R.J.; Vooijs, M.A. A lineage-tracing tool to map the fate of hypoxic tumour cells. Dis. Model. Mech. 2020, 13, 044768. [CrossRef]

72. Zheng, J.; Shen, Y.; Xu, Z.; Yuan, Z.; He, Y.; Wei, C.; Er, M.; Yin, J.; Chen, H. Near-infrared off-on fluorescence probe activated by NTR for in vivo hypoxia imaging. Biosens. Bioelectron. 2018, 119, 141-148. [CrossRef]

73. Hettie, K.S.; Klockow, J.L.; Moon, E.J.; Giaccia, A.J.; Chin, F.T. A NIR fluorescent smart probe for imaging tumor hypoxia. Cancer Rep. 2021, 4, e1384. [CrossRef]

74. Li, X.; Kim, J.; Yoon, J.; Chen, X. Cancer-Associated, Stimuli-Driven, Turn on Theranostics for Multimodality Imaging and Therapy. Adv. Mater. 2017, 29, 1606857. [CrossRef] [PubMed]

75. Gorman, C.M.; Moffat, L.F.; Howard, B.H. Recombinant genomes which express chloramphenicol acetyltransferase in mammalian cells. Mol. Cell. Biol. 1982, 2, 1044-1051. [CrossRef] [PubMed]

76. Saha, D.; Dunn, H.; Zhou, H.; Harada, H.; Hiraoka, M.; Mason, R.P.; Zhao, D. In vivo Bioluminescence Imaging of Tumor Hypoxia Dynamics of Breast Cancer Brain Metastasis in a Mouse Model. J. Vis. Exp. 2011, 56, e3175. [CrossRef] [PubMed]

77. Cecic, I.; Chan, D.A.; Sutphin, P.D.; Ray, P.; Gambhir, S.S.; Giaccia, A.J.; Graves, E.E. Oxygen Sensitivity of Reporter Genes: Implications for Preclinical Imaging of Tumor Hypoxia. Mol. Imaging 2007, 6, 219-228. [CrossRef]

78. Inoue, Y.; Kiryu, S.; Watanabe, M.; Tojo, A.; Ohtomo, K. Timing of Imaging after D-Luciferin Injection Affects the Longitudinal Assessment of Tumor Growth Using In Vivo Bioluminescence Imaging. Int. J. Biomed. Imaging 2010, 2010, 471408. [CrossRef]

79. Cheng, M.H.Y.; Mo, Y.; Zheng, G. Nano versus Molecular: Optical Imaging Approaches to Detect and Monitor Tumor Hypoxia. Adv. Health Mater. 2021, 10, e2001549. [CrossRef]

80. Shao, Q.; Morgounova, E.; Jiang, C.; Choi, J.; Bischof, J.; Ashkenazi, S. In vivophotoacoustic lifetime imaging of tumor hypoxia in small animals. J. Biomed. Opt. 2013, 18, 076019. [CrossRef]

81. Knox, H.J.; Kim, T.W.; Zhu, Z.; Chan, J. Photophysical Tuning of N-Oxide-Based Probes Enables Ratiometric Photoacoustic Imaging of Tumor Hypoxia. ACS Chem. Biol. 2018, 13, 1838-1843. [CrossRef]

82. Umehara, Y.; Kageyama, T.; Son, A.; Kimura, Y.; Kondo, T.; Tanabe, K. Biological reduction of nitroimidazole-functionalized gold nanorods for photoacoustic imaging of tumor hypoxia. RSC Adv. 2019, 9, 16863-16868. [CrossRef]

83. Nyayapathi, N.; Xia, J. Photoacoustic imaging of breast cancer: A mini review of system design and image features. J. Biomed. Opt. 2019, 24, 1-13. [CrossRef] [PubMed] 
84. Cao, X.; Gunn, J.R.; Allu, S.R.; Bruza, P.; Jiang, S.; Vinogradov, S.A.; Pogue, B.W. Implantable sensor for local Cherenkov-excited luminescence imaging of tumor $\mathrm{pO}_{2}$ during radiotherapy. J. Biomed. Opt. 2020, 25, 112704. [CrossRef] [PubMed]

85. Cao, X.; Allu, S.R.; Jiang, S.; Gunn, B.J.R.; Yao, C.; Xin, J.; Bruza, P.; Gladstone, S.D.J.; Jarvis, L.A.; Tian, J.; et al. High-Resolution $\mathrm{pO}_{2}$ Imaging Improves Quantification of the Hypoxic Fraction in Tumors During Radiation Therapy. Int. J. Radiat. Oncol. 2021, 109, 603-613. [CrossRef] [PubMed]

86. Wyatt, J.S.; Edwards, A.D.; Azzopardi, D.; Reynolds, E.O. Magnetic resonance and near infrared spectroscopy for investigation of perinatal hypoxic-ischaemic brain injury. Arch. Dis. Child. 1989, 64, 953-963. [CrossRef]

87. Byrne, P.; Welch, R.; Johnson, M.; Darrah, J.; Piper, M. Serial magnetic resonance imaging in neonatal hypoxic-ischemic encephalopathy. J. Pediatr. 1990, 117, 694-700. [CrossRef]

88. Ishige, N.; Pitts, L.H.; Berry, I.; Carlson, S.G.; Nishimura, M.C.; Moseley, M.E.; Weinstein, P.R. The Effect of Hypoxia on Traumatic Head Injury in Rats: Alterations in Neurologic Function, Brain Edema, and Cerebral Blood Flow. J. Cereb. Blood Flow Metab. 1987, 7, 759-767. [CrossRef]

89. Mirabello, V.; Cortezon-Tamarit, F.; Pascu, S.I. Oxygen Sensing, Hypoxia Tracing and in Vivo Imaging with Functional Metalloprobes for the Early Detection of Non-communicable Diseases. Front. Chem. 2018, 6, 27. [CrossRef]

90. O'Connor, J.P.B.; Robinson, S.P.; Waterton, J.C. Imaging tumour hypoxia with oxygen-enhanced MRI and BOLD MRI. Br. J. Radiol. 2019, 92, 20180642. [CrossRef]

91. Virani, N.; Kwon, J.; Zhou, H.; Mason, R.; Berbeco, R.; Protti, A. In vivo hypoxia characterization using blood oxygen level dependent magnetic resonance imaging in a preclinical glioblastoma mouse model. Magn. Reson. Imaging 2021, 76, 52-60. [CrossRef]

92. Tomaszewski, M.; Quiros-Gonzalez, I.; O'Connor, J.P.; Abeyakoon, O.; Parker, G.; Williams, K.J.; Gilbert, F.; Bohndiek, E.S. Oxygen Enhanced Optoacoustic Tomography (OE-OT) Reveals Vascular Dynamics in Murine Models of Prostate Cancer. Theranostics 2017, 7, 2900-2913. [CrossRef]

93. Howe, F.A.; Robinson, S.P.; McIntyre, D.J.O.; Stubbs, M.; Griffiths, J.R. Issues in flow and oxygenation dependent contrast (FLOOD) imaging of tumours. NMR Biomed. 2001, 14, 497-506. [CrossRef]

94. White, D.A.; Zhang, Z.; Li, L.; Gerberich, J.; Stojadinovic, S.; Peschke, P.; Mason, R.P. Developing oxygen-enhanced magnetic resonance imaging as a prognostic biomarker of radiation response. Cancer Lett. 2016, 380, 69-77. [CrossRef] [PubMed]

95. Kodibagkar, V.D.; Wang, X.; Torres, J.P.; Gulaka, P.; Mason, R.P. Proton imaging of siloxanes to map tissue oxygenation levels (PISTOL): A tool for quantitative tissue oximetry. NMR Biomed. 2008, 21, 899-907. [CrossRef] [PubMed]

96. Shankar, R.V.; Kodibagkar, V.D. A faster PISTOL for 1 H MR-based quantitative tissue oximetry. NMR Biomed. 2019, 32 , e4076. [CrossRef] [PubMed]

97. Shi, X.; Yang, W.; Ma, Q.; Lu, Y.; Xu, Y.; Bian, K.; Liu, F.; Shi, C.; Wang, H.; Shi, Y.; et al. Hemoglobin-mediated biomimetic synthesis of paramagnetic O2-evolving theranostic nanoprobes for MR imaging-guided enhanced photodynamic therapy of tumor. Theranostics 2020, 10, 11607-11621. [CrossRef] [PubMed]

98. Liu, J.; Cabral, H.; Song, B.; Aoki, I.; Chen, Z.; Nishiyama, N.; Huang, Y.; Kataoka, K.; Mi, P. Nanoprobe-Based Magnetic Resonance Imaging of Hypoxia Predicts Responses to Radiotherapy, Immunotherapy, and Sensitizing Treatments in Pancreatic Tumors. ACS Nano 2021, 15, 13526-13538. [CrossRef] [PubMed]

99. Krishna, M.C.; Matsumoto, S.; Yasui, H.; Saito, K.; Devasahayam, N.; Subramanian, S.; Mitchell, J.B. Electron Paramagnetic Resonance Imaging of Tumor $\mathrm{pO}_{2}$. Radiat. Res. 2012, 177, 376-386. [CrossRef] [PubMed]

100. Gertsenshteyn, I.; Giurcanu, M.; Vaupel, P.; Halpern, H. Biological validation of electron paramagnetic resonance (EPR) image oxygen thresholds in tissue. J. Physiol. 2021, 599, 1759-1767. [CrossRef]

101. Kishimoto, S.; Brender, J.R.; Chandramouli, G.V.R.; Saida, Y.; Yamamoto, K.; Mitchell, J.B.; Krishna, M.C. Hypoxia-Activated Prodrug Evofosfamide Treatment in Pancreatic Ductal Adenocarcinoma Xenografts Alters the Tumor Redox Status to Potentiate Radiotherapy. Antioxid. Redox Signal. 2021, 35, 904-915. [CrossRef]

102. Kishimoto, S.; Matsumoto, K.-I.; Saito, K.; Enomoto, A.; Matsumoto, S.; Mitchell, J.B.; Devasahayam, N.; Krishna, M.C. Pulsed Electron Paramagnetic Resonance Imaging: Applications in the Studies of Tumor Physiology. Antioxid. Redox Signal. 2018, 28, 1378-1393. [CrossRef]

103. Bobko, A.A.; Eubank, T.D.; Driesschaert, B.; Khramtsov, V.V. In Vivo EPR Assessment of $p H, p \mathrm{O}_{2}$, Redox Status, and Concentrations of Phosphate and Glutathione in the Tumor Microenvironment. J. Vis. Exp. 2018, 133, e56624. [CrossRef]

104. Yasui, H.; Kawai, T.; Matsumoto, S.; Saito, K.; Devasahayam, N.; Mitchell, J.B.; Camphausen, K.; Inanami, O.; Krishna, M.C. Quantitative imaging of $\mathrm{pO}_{2}$ in orthotopic murine gliomas: Hypoxia correlates with resistance to radiation. Free Radic. Res. 2017, 51, 861-871. [CrossRef] [PubMed]

105. Chen, N.-T.; Barth, E.D.; Lee, T.-H.; Chen, C.-T.; Epel, B.; Halpern, H.J.; Lo, L.-W. Highly sensitive electron paramagnetic resonance nanoradicals for quantitative intracellular tumor oxymetric images. Int. J. Nanomed. 2019, 14, 2963-2971. [CrossRef]

106. Ashkenazi, S.; Cho, D.; Song, C.W. Scanning Tissue Oxygen Needle Probe. In Advances in Experimental Medicine and Biology; Springer: Berlin/Heidelberg, Germany, 2021; Volume 1269, pp. 51-55.

107. Reeves, K.M.; Song, P.N.; Angermeier, A.; Della Manna, D.; Li, Y.; Wang, J.; Yang, E.S.; Sorace, A.G.; Larimer, B.M. 18F-FMISO PET Imaging Identifies Hypoxia and Immunosuppressive Tumor Microenvironments and Guides Targeted Evofosfamide Therapy in Tumors Refractory to PD-1 and CTLA-4 Inhibition. Clin. Cancer Res. 2021, 28, 327-337. [CrossRef] [PubMed] 
108. Hirata, K.; Yamaguchi, S.; Shiga, T.; Kuge, Y.; Tamaki, N. The Roles of Hypoxia Imaging Using 18F-Fluoromisonidazole Positron Emission Tomography in Glioma Treatment. J. Clin. Med. 2019, 8, 1088. [CrossRef]

109. Peeters, S.G.; Zegers, C.M.; Lieuwes, N.G.; van Elmpt, W.; Eriksson, J.; van Dongen, G.A.; Dubois, L.; Lambin, P. A Comparative Study of the Hypoxia PET Tracers [18F]HX4, [18F]FAZA, and [18F]FMISO in a Preclinical Tumor Model. Int. J. Radiat. Oncol. 2015, 91, 351-359. [CrossRef]

110. Quartuccio, N.; Young AIMN Working Group; Laudicella, R.; Mapelli, P.; Guglielmo, P.; Pizzuto, D.A.; Boero, M.; Arnone, G.; Picchio, M. Hypoxia PET imaging beyond 18F-FMISO in patients with high-grade glioma: 18F-FAZA and other hypoxia radiotracers. Clin. Transl. Imaging 2020, 8, 11-20. [CrossRef]

111. Chen, L.; Zhang, Z.; Kolb, H.C.; Walsh, J.C.; Zhang, J.; Guan, Y. 18F-HX4 hypoxia imaging with PET/CT in head and neck cancer: A comparison with 18F-FMISO. Nucl. Med. Commun. 2012, 33, 1096-1102. [CrossRef]

112. More, K.N.; Lee, J.Y.; Kim, D.-Y.; Cho, N.-C.; Pyo, A.; Yun, M.; Kim, H.S.; Kim, H.; Ko, K.; Park, J.-H.; et al. Acetazolamide-based [18F]-PET tracer: In vivo validation of carbonic anhydrase IX as a sole target for imaging of CA-IX expressing hypoxic solid tumors. Bioorganic Med. Chem. Lett. 2018, 28, 915-921. [CrossRef]

113. Gammon, S.T.; Pisaneschi, F.; Bandi, M.L.; Smith, M.G.; Sun, Y.; Rao, Y.; Muller, F.; Wong, F.; De Groot, J.; Ackroyd, J.; et al. Mechanism-Specific Pharmacodynamics of a Novel Complex-I Inhibitor Quantified by Imaging Reversal of Consumptive Hypoxia with [18F]FAZA PET In Vivo. Cells 2019, 8, 1487. [CrossRef]

114. Shimizu, Y.; Motomura, A.; Takakura, H.; Tamaki, N.; Kuge, Y.; Ogawa, M. Accumulation of hypoxia imaging probe "18F-FMISO” in macrophages depends on macrophage polarization in addition to hypoxic state. Ann. Nucl. Med. 2019, 33, 362-367. [CrossRef] [PubMed]

115. O'Neill, H.; Malik, V.; Johnston, C.; Reynolds, J.V.; O'Sullivan, J. Can the Efficacy of [18F]FDG-PET/CT in Clinical Oncology Be Enhanced by Screening Biomolecular Profiles? Pharmaceuticals 2019, 12, 16. [CrossRef] [PubMed]

116. Lopci, E.; Grassi, I.; Chiti, A.; Nanni, C.; Cicoria, G.; Toschi, L.; Fonti, C.; Lodi, F.; Mattioli, S.; Fanti, S. PET radiopharmaceuticals for imaging of tumor hypoxia: A review of the evidence. Am. J. Nucl. Med. Mol. Imaging 2014, 4, 365-384.

117. Qlark, L.C. Monitor and control of blood and tissue oxygen tensions. Trans.-Am. Soc. Artif. Intern. Organs 1956, $2,41-48$.

118. Marland, J.R.; Gray, M.E.; Dunare, C.; Blair, E.O.; Tsiamis, A.; Sullivan, P.; González-Fernández, E.; Greenhalgh, S.N.; Gregson, R.; Clutton, R.E.; et al. Real-time measurement of tumour hypoxia using an implantable microfabricated oxygen sensor. Sens. Bio-Sensing Res. 2020, 30, 100375. [CrossRef]

119. Rivas, L.; Dulay, S.; Miserere, S.; Pla, L.; Marin, S.B.; Parra, J.; Eixarch, E.; Gratacós, E.; Illa, M.; Mir, M.; et al. Micro-needle implantable electrochemical oxygen sensor: Ex-vivo and in-vivo studies. Biosens. Bioelectron. 2020, 153, 112028. [CrossRef] [PubMed]

120. Gray, M.E.; Marland, J.; Dunare, C.; Blair, E.O.; Meehan, J.; Tsiamis, A.; Kunkler, I.H.; Murray, A.F.; Argyle, D.; Dyson, A.; et al. In vivo validation of a miniaturized electrochemical oxygen sensor for measuring intestinal oxygen tension. Am. J. Physiol. Liver Physiol. 2019, 317, G242-G252. [CrossRef]

121. Springett, R.; Swartz, H.M. Measurements of Oxygen In Vivo: Overview and Perspectives on Methods to Measure Oxygen Within Cells and Tissues. Antioxid. Redox Signal. 2007, 9, 1295-1302. [CrossRef]

122. Owen, J.; Logan, K.; Nesbitt, H.; Able, S.; Vasilyeva, A.; Bluemke, E.; Kersemans, V.; Smart, S.; Vallis, K.A.; McHale, A.P.; et al. Orally administered oxygen nanobubbles enhance tumor response to sonodynamic therapy. Nano Sel. 2022, 3, 394-401. [CrossRef]

123. Lukina, M.; Orlova, A.; Shirmanova, M.; Shirokov, D.; Pavlikov, A.; Neubauer, A.; Studier, H.; Becker, W.; Zagaynova, E.; Yoshihara, T.; et al. Interrogation of metabolic and oxygen states of tumors with fiber-based luminescence lifetime spectroscopy. Opt. Lett. 2017, 42, 731-734. [CrossRef] [PubMed]

124. Robinson, M.F.; Dupuis, N.P.; Kusumoto, T.; Liu, F.; Menon, K.; Teicher, B.A. Increased Tumor Oxygenation and Radiation Sensitivity in two Rat Tumors by A Hemoglobin-Based, Oxygen-Carrying Preparation. Artif. Cells Blood Substit. Biotechnol. 1995, 23, 431-438. [CrossRef] [PubMed]

125. Sun, C.-J.; Li, C.; Lv, H.-B.; Zhao, C.; Yu, J.-M.; Wang, G.-H.; Luo, Y.-X.; Li, Y.; Xiao, M.; Yin, J.; et al. Comparing CT perfusion with oxygen partial pressure in a rabbit VX2 soft-tissue tumor model. J. Radiat. Res. 2014, 55, 183-190. [CrossRef]

126. Doss, M.; Zhang, J.J.; Bélanger, M.-J.; Stubbs, J.B.; Hostetler, E.D.; Alpaugh, K.; Kolb, H.C.; Yu, J.Q. Biodistribution and radiation dosimetry of the hypoxia marker 18F-HX4 in monkeys and humans determined by using whole-body PET/CT. Nucl. Med. Commun. 2010, 31, 1016-1024. [CrossRef] [PubMed]

127. Logothetis, N.K. The Underpinnings of the BOLD Functional Magnetic Resonance Imaging Signal. J. Neurosci. 2003, $23,3963-3971$. [CrossRef]

128. Rickard, A.G.; Palmer, G.M.; Dewhirst, M.W. Clinical and Pre-clinical Methods for Quantifying Tumor Hypoxia. In Hypoxia and Cancer Metastasis; Springer: Berlin/Heidelberg, Germany, 2019; Volume 1136, pp. 19-41.

129. D'Alonzo, R.A.; Gill, S.; Rowshanfarzad, P.; Keam, S.; MacKinnon, K.M.; Cook, A.M.; Ebert, M.A. In vivo noninvasive preclinical tumor hypoxia imaging methods: A review. Int. J. Radiat. Biol. 2021, 97, 593-631. [CrossRef]

130. AlSawaftah, N.; Farooq, A.; Dhou, S.; Majdalawieh, A.F. Bioluminescence Imaging Applications in Cancer: A Comprehensive Review. IEEE Rev. Biomed. Eng. 2021, 14, 307-326. [CrossRef]

131. Torres, J.P.; López-Larrubia, P.; Ballesteros, P.; Cerdán, S. Imaging tumor hypoxia by magnetic resonance methods. NMR Biomed. 2010, 24, 1-16. [CrossRef] 
132. Stieb, S.; Eleftheriou, A.; Warnock, G.; Guckenberger, M.; Riesterer, O. Longitudinal PET imaging of tumor hypoxia during the course of radiotherapy. Eur. J. Pediatr. 2018, 45, 2201-2217. [CrossRef]

133. Lee, C.-T.; Boss, M.-K.; Dewhirst, M.W. Imaging Tumor Hypoxia to Advance Radiation Oncology. Antioxid. Redox Signal. 2014, 21, 313-337. [CrossRef]

134. Daponte, A.; Ioannou, M.; Mylonis, I.; Simos, G.; Minas, M.; E Messinis, I.; Koukoulis, G. Prognostic significance of HypoxiaInducible Factor 1 alpha(HIF-1alpha) expression in serous ovarian cancer: An immunohistochemical study. BMC Cancer 2008, 8, 335. [CrossRef] [PubMed]

135. Ilie, M.; Mazure, N.M.; Hofman, V.; Ammadi, E.R.; Ortholan, C.; Bonnetaud, C.; Havet, K.; Venissac, N.; Mograbi, B.; Mouroux, J.; et al. High levels of carbonic anhydrase IX in tumour tissue and plasma are biomarkers of poor prognostic in patients with non-small cell lung cancer. Br. J. Cancer 2010, 102, 1627-1635. [CrossRef] [PubMed]

136. Nordsmark, M.; Loncaster, J.; Aquino-Parsons, C.; Chou, S.-C.; Gebski, V.; West, C.; Lindegaard, J.C.; Havsteen, H.; Davidson, S.E.; Hunter, R.; et al. The prognostic value of pimonidazole and tumour $\mathrm{pO}_{2}$ in human cervix carcinomas after radiation therapy: A prospective international multi-center study. Radiother. Oncol. 2006, 80, 123-131. [CrossRef] [PubMed]

137. Dunwoodie, S.L. The Role of Hypoxia in Development of the Mammalian Embryo. Dev. Cell 2009, 17, 755-773. [CrossRef]

138. Chen, P.-S.; Chiu, W.-T.; Hsu, P.-L.; Lin, S.-C.; Peng, I.-C.; Wang, C.-Y.; Tsai, S.-J. Pathophysiological implications of hypoxia in human diseases. J. Biomed. Sci. 2020, 27, 63. [CrossRef]

139. Digiacomo, J.W.; Gilkes, D.M. Tumor Hypoxia as an Enhancer of Inflammation-Mediated Metastasis: Emerging Therapeutic Strategies. Target. Oncol. 2018, 13, 157-173. [CrossRef]

140. Digiacomo, J.W.; Gilkes, D.M. Therapeutic Strategies to Block the Hypoxic Response. In Hypoxia and Cancer Metastasis; Springer: Berlin/Heidelberg, Germany, 2019; Volume 1136, pp. 141-157. 